\title{
Primary caregivers' values of play and creativity in early childhood in relation to children's academic self-esteem
}

Jill M. Martino

West Virginia University

Follow this and additional works at: https://researchrepository.wvu.edu/etd

\section{Recommended Citation}

Martino, Jill M., "Primary caregivers' values of play and creativity in early childhood in relation to children's academic self-esteem" (2009). Graduate Theses, Dissertations, and Problem Reports. 780.

https://researchrepository.wvu.edu/etd/780

This Thesis is protected by copyright and/or related rights. It has been brought to you by the The Research Repository @ WVU with permission from the rights-holder(s). You are free to use this Thesis in any way that is permitted by the copyright and related rights legislation that applies to your use. For other uses you must obtain permission from the rights-holder(s) directly, unless additional rights are indicated by a Creative Commons license in the record and/ or on the work itself. This Thesis has been accepted for inclusion in WVU Graduate Theses, Dissertations, and Problem Reports collection by an authorized administrator of The Research Repository @ WVU. For more information, please contact researchrepository@mail.wvu.edu. 
Primary Caregivers' Values of Play and Creativity in Early Childhood in Relation to Children's Academic Self-esteem

\title{
Jill M. Martino
}

Thesis submitted to the College of Human Resources and Education at West Virginia University in partial fulfillment of the requirements for the degree of

\author{
Master of Arts \\ In Educational Psychology \\ With an emphasis in \\ Child Development and Family Studies
}

Barbara G. Warash, Ed.D., Co-Chair

Amy Kennedy Root, Ph.D., Co-Chair

Joy Faini Saab, Ed.D.

Department of Technology, Learning, and Culture

Morgantown, West Virginia

2009

Keywords: play, creativity, early learning standards, value Copyright 2009 Jill M. Martino 
Primary Caregivers' Values of Play and Creativity in Early Childhood in Relation to Children's Academic Self-esteem

Jill M. Martino

\section{Abstract}

There is currently a trend to push academics due to laws such as the No Child Left Behind Act (2001) which holds schools accountable for academic learning. Play and creativity are being eliminated in early childhood even though theorists state the value of these elements in the overall development of young children. The purpose of the study was to examine the primary caregivers' values of play and creativity in early childhood and their child's academic self-esteem. Primary caregivers recruited from a university preschool completed the Parent's As A Teacher Inventory (PAAT) and the teachers of the school rated the children using the Behavioral Academic Self-Esteem (BASE) scale. It was found that primary caregivers valued play and creativity. They placed the endorsement of play and creativity over that of academics. Findings revealed that primary caregivers' value of play was a significant predictor of a child's self- confidence. 


\section{Acknowledgements}

First of all I would like to thank my parents, Phil and Diana, for always being there for me every step of the way and believing in me. You saw my true potential and helped me run with it. I could not have done this with out your undying love and support. Thank you as well to my brother, Brian, for being loving, supportive, and providing me with some comic relief. I love you all very much!

To my committee members Dr. Amy Kennedy Root, Dr. Bobbie Warash, and Dr. Joy Saab: Thank you for your willingness to help, you inspiration, words of wisdom, and guidance. I would be lost with out your direction.

Thank you to Mrs. Diana and Mrs. Melissa, teachers at the WVU Nursery School, for their help in completing the Behavioral Academic Self-Esteem (BASE) on the children.

I would also like to thank Mrs. Barbara Pavel- Alvarez for her constant emotional support. You too believed in me and helped guide me with your encouraging words.

To Judy Martin, our Child Development and Family Studies Secretary, thank you for your support and help with any questions or concerns I had. You made this process so much easier for me. I truly appreciate it.

Last but not least, thank you to all my Masters in Child Development and Family studies classmates and all my friends. I'm so thankful for our small close knit class that builds each other up and inspires one another to succeed even when times are rough. To all my other friends, thank you for your patience with me and your understanding. You support is truly appreciated and valued. 


\section{Table of Contents}

$\begin{array}{lc}\text { Abstract } & \text { ii } \\ \text { Acknowledgments } & \text { iii } \\ \text { Table of Contents } & \text { iv } \\ \text { List of Table } & \text { vi } \\ \text { List of Figures } & \text { vii }\end{array}$

Chapter I

Introduction 1

Chapter II

Review of Literature $\quad 9$

$\begin{array}{ll}\text { Play and Creativity } & 9\end{array}$

The value of play and creativity 13

$\begin{array}{ll}\text { Self-esteem } & 14\end{array}$

Parental Contributions to Academic Self-esteem 18

Creativity and self-esteem 20

Parents' value of play and creativity $\quad 22$

$\begin{array}{ll}\text { Summary } & 24\end{array}$

Chapter III

Methods

Sample 26

$\begin{array}{ll}\text { Participants } & 26\end{array}$

$\begin{array}{ll}\text { Procedures } & 27\end{array}$

$\begin{array}{ll}\text { Measures } & 27\end{array}$

Parents As Teacher Inventory. $\quad 27$

Behavioral Academic Self-esteem. 29 
Chapter IV

Results

Descriptives $\quad 31$

Analysis $\quad 33$

Chapter V

Discussion

Interpretation of Results $\quad 36$

Limitations $\quad 40$

Future Directions $\quad 40$

General Conclusion $\quad 41$

$\begin{array}{ll}\text { References } & 43\end{array}$

Appendices

Appendix A: Cover Letter $\quad 53$

Appendix B: Parent As A Teacher Inventory $\quad 59$

Appendix C: Academics $\quad 66$

Appendix D: Parent Form $\quad 68$

Appendix E: Behavior Academic Self-esteem $\quad 71$

$\begin{array}{ll}\text { Curriculum Vitae } & 74\end{array}$ 


\section{List of Tables}

Table 1-Means and Standard Deviations 31

Table 2-Correlations $\quad 32$

Table 2-correlations continued $\quad 32$

Table 3-Regression analyses predicting BASE $\quad 35$

Table 3 -Regression analyses predicting BASE continued 35 
List of Figures

Figure 1 


\section{Chapter 1}

\section{Introduction}

There is currently a major emphasis on academic achievement and success in the early childhood years which has minimized the importance of play and creativity (Drew, Christie, Johnson, Meckley, \& Neil, 2008). The pressure to have young children succeed in academics is often attributed to the accountability requirements of educational policies and laws that must be followed. The No Child Left Behind Act of 2001, PL 107-110 is one such law that has had a great impact on the academic community including prekindergarten education. This law created as the reauthorization of the Elementary and Secondary Education Act, mandates nation-wide, test-based accountability for schools receiving federal money (McAfee \& Leong, 2007). As a result of this law, 32 states have approved high quality standards according to No Child Left Behind, "which ensures that all children receive a quality education" (U.S Department of Education, 2005, p.1). Academics are emphasized so much that under this law, parents have the choice to transfer their child to a different school if the school is not accountable academically or not making the necessary improvements for a quality education. States want to ensure that no child is left lacking the basic skills needed in our society by setting such standards and holding schools accountable academically. Six principles of the No Child Left Behind law include accountability for academic results (e.g., passing tests), school safety (e.g., low incidence of altercations), parental choice (e.g., for their child's education), teacher quality (e.g., experienced and knowledgeable educators), scientifically-based methods of teaching (e.g., proven techniques for successful student learning), and local flexibility (e.g., in teacher's requirements and state funding) (Amatea, 2009, p. 27). 
These policies and laws send powerful messages to parents and educators that an academic environment is preferred to one where play is the primary source for learning. Academic pre-kindergarten is in contrast to many child development theorists such as Elkonin (1978), Vygotsky (1978), Parten (1932), Gardner (1983) and Piaget (1962), who feel that young children should be children, free and open to the opportunity to indulge in play and creative expression. Vygotsky, in particular, held a constructivist view that children use past experiences in play and learning to interpret their own effort and motivation (Van Hoorn, Nourot, Scales \& Alward, 2003; Vygotsky, 1978).

With the onset of accountability, early learning standards for pre-kindergarten have been developed to set the bar for achievement (Schiller \& Willis, 2008). "All states and the District of Columbia have approved early learning standards for preschoolers as an element of reform to shape content and curriculum" (Drew et al, 2008, p. 38). These standards are described as outcomes of learning which young children should achieve. The Early Childhood Education Assessment Consortium of the Council of the Chief School Officers (CCSSO) (as cited by Gronlund \& Koralek, 2008) defines early learning standards as, "statements that describe expectations for the learning and development of young children across the domains of: health and physical well-being; social and emotional well being; approaches to learning; language development and symbol systems; and general knowledge about the world around them" (p. 10). These standards provide a framework for educators to establish expectations and commonalities at each age level. Even though academics standards prevail for pre-kindergarten through elementary, most state standards include social and emotional goals of pre-kindergarten age children (Logue, 2007). In classrooms where social and emotional standards are 
valued there is great potential for enriched learning environments. With planning, knowledge on current research, and creative thinking, teachers can promote learning and exploration that support the learning standards (Schiller \& Willis, 2008). However, Pre-K standards are not uniform and vary from state to state which leaves much interpretation to local educators and the possible elimination of the opportunity to play and other childhood means of learning (Bredekamp \& Copple, 2009).

Even though theorists Vygotsky (1978) and Piaget (1962) are clear about the importance of play (Van Hoorn et al, 2003) and creativity (Bunker, 1991) in the development of young children, there is a nationwide trend to push down the curriculum in order to obtain academic results in pre-kindergarten classrooms. More and more preschools are using kindergarten benchmarks for pre-kindergarten (Bodrova, Leong, Hensen \& Henninger, 2000). Readiness for kindergarten has been gauged on the standards set for preschool-aged children. Kindergarten and early childhood teachers feel overwhelmed with these standards and required curriculum goals (Helm, 2008). These types of standards often lead to "cookie cutter" curriculums, which focus on prescribed lessons (e.g. worksheets and coloring sheets). In some states, such as Florida, the prekindergarten teacher is responsible for the success of their class in kindergarten and can be reprimanded for children not acquiring the academic skills needed in kindergarten (Finn, 2008).

The intent of early learning standards are good but can drive teachers to use more inappropriate academic activities so children can learn the content that is on the assessment. Hence, play is often the neglected aspect in this scenario and its existence in preschools has changed drastically in the past 20-30 years (Bodrova \& Leong, 2003). 
This is a cause for concern as play serves as the bridge or vehicle for learning in early education and meeting academic standards (Bodrova et al, 2000). Concepts associated with play are positive and give children a positive attitude toward academics and learning. The National Association for the Education of Young Children (NAEYC) states in their position statement that play is at the heart of the developmentally appropriate practice and should be a key instructional strategy in the early years (Johnson, Christie,\& Wardle, 2005). Researchers (Bodrova et al., 2000) say play enables children to develop a certain level of maturity in their cognitive abilities which helps them to develop a sense of self (Entwisle, Alexander, Pallas \& Cadigan, 1987). Children grow and learn within the context of positive social relationships that occur when they have the opportunity to play. Vygotsky (1978) was one who believed that mature play assisted children to self regulate their behavior. Pretend play, or acting our familiar routines, serves as a key developmental tool for later outcomes, including a sense of purpose in the child and a support for understanding the world which continues from play in pre-k to academic work in the school-age years (Gross, 2008). Play according to Vygotsky works as a transitional stage for disconnecting thought from certain objects. Children initially use objects to represent ideas, situations, and other objects known as "pivots" which work as anchors for representation and meaning in the child's mental world (Van Hoorn, et al, 2003; Frost, Wortham, \& Reifel, 2005).

Recognizing the importance of play, some states such as Arizona are working to incorporate constructive play, where children manipulate materials with an intention of creating something (Rubin, 2008), into their standards. For example, play centers in these schools have "literacy enhanced" play centers equipped with labels and materials for 
children to create their own ways to categorize and name materials (Drew et al, 2008). Therefore, it appears that evidence strongly supports the need for play as important tool for learning in the early years.

A preschool curriculum also plays a lead in the type of program available to young children. If a chosen preschool curriculum is academic rather than play oriented then this sends a message that play is rendered as frivolous. In hopes to avoid a structured academic curriculum for preschool-aged children, states such as West Virginia have approved three curriculums that are developmentally appropriate, and incorporate play and creativity into the lessons. These include, Creating Child-Centered Classrooms: 3-5 Year Olds (1997), The Creative Curriculum Fourth Edition (2002), and Educating Young Children Second Edition (2002) (West Virginia Department of Health and Human Resources, 2003). Even though the intention of requiring one of these curriculums is evident, it still has not eradicated the overall race for young children to succeed on academic skills (Bodrova \& Leong, 2003). For some educators, play interferes with the educational mission of school. In fact, recently there has been an effort to eliminate recess, the creative arts, and physical education; even though there is substantial research supporting its educational value, and a lack of evidence supporting the contrary (Pellegrini, 2008; Ginsburg, 2007). Early childhood classrooms are becoming more academically oriented and rigorous, with the belief from curriculum designers that "earlier is better" for academic skills to be drilled, and play activities to be minimized (Isenberg \& Jalongo, 1997).

In West Virginia, to help prevent an over emphasis on academics, West Virginia's Universal Access to a Quality Early Education System (Policy 2525) (West Virginia 
Department of Education, 2005), states that creativity is the foundation for new ideas. In this policy, it is acknowledged that creative thinking builds problem-solving skills, conflict resolution, leadership, and life-long learning. Teachers can support creativity by implementing long term projects that children initiate such as the project work which applies activities and lessons to the children's interest allowing them to explore, observe, research, and question the world around them (Hewett, 2001). Project work allows children to develop and express themselves through artistic representation enhancing every developmental domain. No matter the intention of the Policy 2525, Pre-K teachers are held accountable and therefore an emphasis on producing academic results is still prevalent.

The implementations of pre-kindergarten academic environments impact the expectations that parents have for their children (Johnson et al, 2005). Many parents recognize the place for play in the early years, yet worry that overemphasis of play in school will cause their child to suffer academically. A local ad by the Sylvan Learning Center (Sylvan Learning, 2008) advertises that they can help a preschooler become ready for kindergarten in math, reading, etc. when in fact the National Association for the Education of Young Children (NAEYC) states that kindergartens should be ready for the children no matter their developmental level. Play and creativity according to child development experts is the vehicle for learning (Cornett, 2003; Johnson et al, 2005; Bodrova et al, 2000; Isenberg \& Jalongo, 1997). With the push for academic results in pre-kindergarten, do parents feel this pressure to have their young children excel? Do they value play and creativity as an important and essential element to the child's 
growth? Do parents who value play and creativity have children who reach their academic potential?

Self-esteem is another factor that can suffer when young children are in an academic environment they are not ready for. Academic self-esteem refers to the child's ability to choose their experiences and explorations in which they have control and are able to build confidence in the world around them. Early childhood programs should aim at developing a sense of self in children, and not over shadow the importance of socioemotional development with "pushed" academic skills (Warash, et al, 2000; Raver, 2002). Even though pre-kindergartens are viewed as places where formal school readiness occurs (Bodrova et al, 2000), a child's academic self-esteem is also a part of the overall academic success and is predictive of later success in such areas as language and literacy as well as the development of a positive self concept, appropriate social interaction and relationships; knowledge of family and community; and positive approached to learning (West Virginia Department of Health and Human Recourses, 2003). These factors interrelate to help a young child develop a positive academic selfesteem, an entity that contributes to the child's academic success.

This study investigated the value primary caregivers place on play. It investigated to see if young children who have high academic self-esteem have primary caregivers who value play and creativity. The questions are as follows: (1) Do primary caregivers value play? (2) Do primary caregivers value creativity? (3) Is there a difference in primary caregivers' value of academics versus play? Is there a difference in primary caregivers' value of academics versus creativity? (4) Is there a positive correlation between primary caregivers' endorsement of play and creativity and children's BASE 
scores? This would certainly add to the knowledge that primary caregivers can be comfortable with encouraging play and still have children be successful academically in pre-kindergarten. 


\section{Chapter II}

\section{Review of Literature}

The review is divided into the following sections: play and creativity, the value of play and creativity, parental values of play and creativity including aspects of selfesteem, and academic self-esteem.

\section{Play and Creativity}

Play and creativity work together to create a stimulating environment for proper child development. Torrence (2001) defines play as, "an activity which is nonliteral, intrinsically motivated, process-, rather than product-oriented, freely chosen, pleasurable, and free from externally imposed rules" (p. 8). Creativity has been defined as a process of thinking and responding to experiences and stimuli (Isenberg \& Jalongo, 1997). The constructs of play and creativity go hand-in-hand, as creativity may first be expressed via children's play, specifically children's pretend play. Creativity according to Torrance (1974) is the process of sensing problems or gaps in information as well as forming ideas or hypotheses, testing and modifying these hypotheses, and communicating the results.

Carl Rogers (1954) posed conditions for creativity including psychological safety, internal locus of evaluation, willingness to toy with ideas, to play with new possibilities, and openness to experience. Psychological safety describes a warm and stable environment for creating as well as a child's attitude. Internal locus of evaluation consists of a child's self confidence and independence.

Theorists have stated that play is a primary learning tool for children (e.g., Elkonin, 1978; Parten, 1932; Piaget, 1962, Vygotsky, 1978). Indeed, Piaget's cognitive developmental theory states that children support their development through problem 
solving skills that occur during play. In the early years of life, parents may help to facilitate this process of problem solving by encouraging developmentally appropriate play in their children. According to Piaget (1962), children develop play skills from simple to complex, and these trends occur as children develop their play in areas including physical growth of mind and body, elaboration and complexity of their play, controlling their plans and ideas (beginning to use imagination), and creating a greater experiential understanding (using causal relationships for pretend play) (Rogers \& Sawyers, 1988).

In the beginning, children spend a majority of their time focusing on observations and adaptations on how to survive, a term described by Piaget as "nonplay" (1962); however, these nonplay behaviors are essential for the development for future play skills. For instance, during sensorimotor development children observe their actions and practice using their reflexes, which Piaget called primary circular reactions. These primary circular reactions eventually lead to secondary circular reactions, where children begin to grasp (manipulate) objects to explore and play in their world. Next, children will begin to engage in more intentional acts, specifically they begin to bring objects together that are unrelated (Gross, 2008). Further, they engage in functional play which is the use of intentional actions to discover their environment. Then, young children will engage in the coordination of secondary schemata, where they use skills from past experiences in new endeavors, however manipulation of objects is still the main way of playing. Around the child's first birthday, they begin to find new ways of achieving goals known as tertiary circular reactions which is the exploration of properties of objects by acting upon them in new ways (Rogers and Sawyers, 1988). This is also described as the 
"child as the scientist" stage. Between 12 and 18 months children start showing early stages of pretend play. In functional relational play children use objects to portray what they understand from their world. Better put, children will begin to bring together objects and make meaning such as a child using a spoon to stir in a cup. According to Piaget (1962) children in the first two years of life play use their sensorimotor skills (sight, touch, hearing, smell, and taste) and through the manipulation of objects. Play continues, and becomes more advanced, through the preoperational years (2-7).

Indeed, during this stage, children show cognitive growth. They are able to classify objects from observations, exploration and experiences. These concepts are based on the ideas of Piaget (1962) and include conservation, seriation, and spatial relationships (Rogers \& Sawyers, 1988). It is also during this time that children begin to engage in constructive play (such as using blocks or puzzles), which tends to be the most common type of play among middle class preschoolers (Rogers \& Sawyers, 1988). Children in preschool begin to interact socially with peers and begin play involving body movement, expression, and language development. Further, during early childhood, children's play becomes advanced; and they begin to engage in make-believe or symbolic play (Scarlett, Naudeau, Pasternak, \& Ponte, 2005). According to Piaget (1962) and neo-Piagetians (e.g., Case, 1998), symbolic, or pretend, play offers children with a wide-range of opportunities to problem solve and role play, which has implications for children's cognitive development.

Piaget (1962) also stated that children learn through a process of adaptation and (re)organization, which takes place via assimilation and accommodation. Assimilation occurs in children when they incorporate new elements or experiences in to what they 
already know about their world (Van Hoorn, Nourot, Scales \& Alward, 2003). In assimilation, familiar objects are simplified to fit categories by using information. Accommodation is used when the child is involved in a new learning experience and new categories are created to "fit" the new information. This process allows the child to create new patterns of thinking during their experience. Children accommodate, or change the ideas they have, to fit real life situations. Therefore, children modify their understanding of their environment to fit their own needs (Piaget, 1962).

Indeed, play offers children ample opportunities to adapt and reorganize their existing mental structures. For example this takes place through Piaget's notion of adaptation. Adaptation is the link between play and learning. Play allows children to practice skills and concepts through accommodation. Piaget believes that play develops skills for further learning later in life (Johnson et al, 2005). Children begin using these play skills by organizing their experiences which is known as adaptation.

Since play is so important to children's learning (Piaget, 1962), it seems essential that children's play behaviors and interests should influence the academic curriculum. Play fuels motivation for academics by integrating social skills and promoting emotional regulation (Izard, 2002). Children do not have to be reinforced or rewarded for playing. Play is a pleasure in itself and intrinsic motivation for learning in academics. Pleasurable feelings offer a sense of fun and children link fun to academics through play (Johnson et al, 1999). Therefore, it should not be surprising that there have been numerous studies that have linked play and creativity to advancement in other domains of development. 
The value of play and creativity

The importance of play has been noted by many professional organizations such as the National Association for the Education of Young Children (NAEYC) and the Association for Childhood Education in their affirmations of healthy growth and development. "Play enables children to make sense of their world, develop cultural and social understanding, express their thoughts and feelings, foster divergent thinking, meet and solve real problems, and develop language skills and concepts" (Isenberg \& Jalongo, 1997, p. 45).

The benefits of play for children are phenomenal. Numerous factors include promoting a sense of personal power, competence, a positive outlook about themselves and learning (Harris, 2000; Youngblade \& Dunn, 1995). "Vygotsky, in his socio-cultural theory, believed that play was the activity that would produce the most positive developmental outcomes" (Innovations, 2004, p. 8). Imagination, as found through pretend play, is an expression of emotions and ability to control actions (Lindqvist, 2003). Piaget relied heavily on the outcomes related to the use of manipulatives for play in the classroom. As noted by Singer (1973) in the article "Montessori and Play: Theory vs. Practice" by Torrence (2001) "A consequence of make-believe play for the child is an increasingly differentiated self-concept or awareness of self. In effect, by practicing a variety of make-believe selves and roles, a child gradually differentiates himself out of the field around him." (p. 206). Further, children who engage in play develop creativity, healthy brain development, and master exploratory skills (Ginsburg, 2007). Moreover, play has been related to gains in confidence and resilience during challenges, including those related to academics. 
Johnson and colleagues, (1999) stated that, "The phenomenon of play is a holistic and integrated within the individual personality and self identity of the player" (p. 46). Peller (1952), according to Johnson, Christie \& Yawkey (1999) believed that playful representation is a step toward forming a self concept. Play also helps a child to establish empathy which, in turn, gives children a positive sense of self and positive outlook on others. The child is in control of their own play enabling them to develop a sense of self and control of their own environment. Thus, it appears that one important area that play fosters is the development of the self-system. Below is an outline of the aspects of selfesteem, and academic self-esteem which is accentuated through play.

\section{Self-esteem}

Self-esteem is an entity combining personality and one's abilities. Personal control is one component of self concept, the other is self-esteem. According to Ross and Broh (2000), "Self-esteem is the perception of oneself as a person of worth, and sense of control is a perception of oneself as an effective person" (p. 271).

Sense of self-worth is related to the degree in which individuals feel valued (Cast $\&$ Burke, 2002). People who tend to be in control of their lives also tend to have positive self-esteem. Self-esteem has been related to education in three major ways. The first conceptualization is that self-esteem is an outcome of academics and successful experiences. Secondly, self-esteem can work as a self motivator in which individuals seek to maintain or increase their personal views of one's self; indeed, some researchers believe that self-esteem works to improve academic achievement (Ross \& Broh, 2000). Lastly, self-esteem works as a buffer to help provide protection from harmful experiences 
such as the inability to complete a challenge, be it academic or other (Cast \& Burke, 2002).

Empirical work on self-esteem indicates that a sense of control results in successful academic achievements (Johnson et al, 1999). For instance, in a study by Ryan and colleagues (1994) attachment to parents, attachment to teachers, self-esteem and academic achievement was examined in 606 middle school students. In this study, they administered the following questionnaires: the Inventory of Adolescent Attachments, the Academic Coping Inventory, and the Self-Regulation Questionnaire-Academic, and the Multidimensional Self-esteem Inventory (MSEI); and they found that self-esteem and school functioning were predicted by an individual's relationship quality with teachers, parents, and friends. It may be possible that these quality relationships in turn may be associated with development of education and academic self-esteem. In fact, self-esteem is believed to improve academic achievement and is an important correlate in psychology (Flouri, 2006). High self-esteem promotes learning not only in the preschool years but in advanced stages of schooling. Academic achievement rests on a firm foundation of social and emotional skills, such as self-esteem (Raver, 2002, p. 4). A rich school environment aids in providing children with ideas and experiences that form a sense of "self". "Child development relates to academic self-image for two reasons. First, a child's self-image can be an outcome of schooling. As well, the child's concept of self can influence outcomes, especially school achievement" (Entwisle et al, 1987, p. 1191). Self-esteem acts as a mediator of schooling. Children who have positive attitudes about school have confidence in their schooling, stay in school longer, and seek help to persist in troubling time. Academic skills and emotional adjustment are bidirectional, each affecting the 
other. If a child is successful academically they will have a greater self-esteem or worth, whereas if the child struggles they will have a negative self worth making it difficult for them to succeed academically (Raver, 2002).

Thus, it may be that academic achievement is related to a high sense of personal control. There have been studies investigating more specific areas of children's selfdevelopment, including academic self-esteem. Academic self-esteem is a specific form of self-esteem which is observed in the classroom setting, and can be reflected in how children becomes effective in exploration and dealing with change in their environment (Warash \& Markstrom, 2001).The actual process for children developing an academic self-image is not very clear; however it is clear that academic achievement is associated with a high sense of control and supportive social relationships. For instance, Ross and Broh (2000) proposed that supportive relationships increase a child's self-esteem and sense of personal control. Data from the National Educational Longitudinal study included 24,599 8th graders from 1,503 public schools in the United States was used in the study. Follow-ups were conducted at 2- and 4-years, and when the students were in $10^{\text {th }}$ and $12^{\text {th }}$ grades. Academic achievement, self-esteem, locus of control (sense of personal control), and social demographics were measured and collected. The study found that performing well in school and parental support in the $8^{\text {th }}$ grade helps an individual feel in control of their life in the $10^{\text {th }}$ grade, which shapes subsequent academic success in the $12^{\text {th }}$ grade, perhaps working in a "self- amplifying" feedback loop. However, the measure of self-esteem in the $10^{\text {th }}$ grade did not appear to mediate the relationship between academic performance in the $8^{\text {th }}$ grade and academic achievement in 
the $12^{\text {th }}$ grade. Primary caregivers' that are supportive aid in a child's development of self-esteem thus enhancing their academic performance.

Early self-theorists state that self-esteem promotes effective coping when children express themselves in an academic setting where they are responsible for their actions and can control their success (Bunker, 1991). Not only does self-image come from the school environment but from outside experience as well. In general, children make and test their own hypothesis about themselves and gain concepts in all aspects and environments of life (Entwisle et al, 1987, p. 1192). Entwisle and colleagues (1987) studied the impacts of self image on academic success in first graders. It was theorized that characteristics such as sex, race, and socioeconomic status would affect cognitive outcomes, and thus academic self-esteem (Entwisle et al, 1987). Data from a Beginning School Study in the fall of 1982 from 20 Baltimore City Elementary Schools was used. Stratified random sampling procedures were used to ensure an equal sample. Eight hundred parents and 673 children were assessed. Parents provided data through selfreport measures. Parents completed Dickstein's (1972) test on academic self-esteem to assess children's academic self-image. They reported that academic self-image was predicted by child sex, but not race. The researchers concluded that significant findings illustrated the importance of peers and others to girl's academic self-image. Further, for African American girls, academic self-image was predictive of academic performance in the first grade. Thus it appears that (1) relationships affect the development of selfesteem, and (2) academic self-esteem is related to academic achievement (Entwisle et al, 1987). 


\section{Parental Contributions to Academic Self-esteem}

Academic self-esteem in children is accentuated by parents' involvement in their child's schooling. Parents provide support for successful accomplishment of tasks aiding in development of self-esteem and thus academic self-esteem. Although little attention has been paid to parental relations and academic achievement, it is evident that parents have a tremendous impact on their child's academic self-esteem (Gaffield, 1994; Flouri, 2006). In a study by Wagner and Phillips (1992) relations between parental behavior and children's perception of their academic abilities were reviewed. Children's academic competence was expected to be correlated with parental warmth and involvement. Data from 81 children in 15 schools were used. Of, all families that participated, $73 \%$ were white and middle class. Mother-child and father-child interactions were measured via video tape, and later coded. Surprisingly, mother's behavior was unrelated to children's self-perceptions of academic competence. Lack of evidence in this study may be due to a small sample size; therefore it requires additional study.

Even though, Wagner and Phillips (1992) did not find a significant relation between parenting and academic self-esteem, another study with preschool-aged children did reveal significant findings. Specifically, in a study on parenting styles and the development of academic self-esteem by Warash and Markstrom (2001) parents' involvement with their children influenced the children's school performance and confidence. Children age three to five years who attended a major university laboratory school were assessed using the Behavioral Academic Self-esteem (BASE) rating scale which is a 16-item teacher observation. Parents reported their own feelings of warmth and autonomy toward their child. Mothers' aspects of guilt and anxiety were found to 
positively affect a students' self-esteem in regard to their initiative in school (Warash \& Markstrom, 2001).

Flouri (2006) states that few studies have addressed whether mothers' interest in children's education are linked to children's self-esteem. This British longitudinal study was conducted with 17,000 children. Follow-ups were conducted at 5, 10, 16, and 26 years of age. The final sample consisted of 4,003 participants including 1,737 men and 2,033 women. Educational attainment was measured at age 26 grouping participant in six categories from $0=$ "no qualifications" to $5=$ "first degree or higher" in relation to National Vocational Qualification levels. At age 10, children's teachers reported mother's and father's interests in their child's education. Self-esteem was also measured using a 12-item scale. Approximately 55\% of mothers indicated they were very interested in their child's education at 10 which was predictive of educational attainment. In addition, self-esteem was found to be a significant predictor of educational attainment in both males and females. However, mothers' interest in their children's educational attainment did not predict actual educational attainment when assessed via its impact on children's self-esteem. Thus primary caregivers' involvement appears and self-esteem appears to influence schooling.

Parenting styles and involvement in their children's lives seem to be imperative to their academic success and their development of academic self-esteem (Raver, 2002). A positive emotional outlook on learning influences a positive academic self-esteem, which likely influences academic readiness/performance. Indeed, parental warmth and support have been shown to be predictive of positive self-perceptions and academic abilities (e.g., Ryan et al., 1994; Wager \& Phillips, 1992). Together parents, teachers, and 
administrators can work to create an environment linking play, creativity, and academic skills to fully benefit children in pre-kindergarten settings.

\section{Creativity and self-esteem}

High creativity is associated with independence, autonomy, and self-confidence, which in turn is associated with high self-esteem (Kemple, David, \& Wang, 1996). The association between creativity and self-esteem has been illustrated in empirical work. For instance, in one study, 103 third grade students from North Carolina were assessed using the Coopersmith Self-esteem Inventory (1982) which measured statements on selfworth in a creative task. Participants were divided in to groups based on intrinsic rewards or no reward. Each student made a collage and was graded by judges on their creativity. Gerrard, Poteat, and Ironsmith (1996) found that self-esteem was shown to be positively related to creativity.

Indeed, theorists have stressed that children's creative expression is a way of promoting academic self-esteem in early childhood (Gardner, 1983). Art, drama, and music have historically been the chief means through which people construct meaning (Cornett, 2003). Piaget stated that creativity is based on the child's cognitive level and intellect (Isenberg \& Jalongo, 1997). Further, Vygotsky (1978) stated that creativity is essential to the existence of humanity and society (Lindgvist, 2003) and believed that children need to engage in activities that elevate their level of thinking and functioning (Isenber \& Jalongo, 1997; Smolucha, 1989).

Pre-kindergarten classrooms that develop an aspect of creativity and play and promote their importance tend to have children with higher self-esteem (Kemple et al, 
1996). More specifically, these classrooms have children who display positive outcomes, such as feeling good about themselves in school and the development of a stronger selfesteem among the their peers (Isenberg \& Jalongo, 1997). Further Kemple and colleagues (1996) studied creativity and self-esteem in preschoolers. There were 64 five year-old children, their mothers, and day care teachers participated in the study. The daycares were located in two small midwestern towns. All of the children observed were Caucasian and spoke English. Mothers and teachers completed the Emotionality, Activity, and Sociability (EAS) Temperament Scale which included 25 items ranked on a 5-point likert scale, as well as a 24 item Behavioral Referents of Presented Self-Worth Scale. Children were assessed using the Perdue Self Concept Scale, a 40 item pictorial measure. Children who had creative potential were likely to possess high levels of selfesteem (Kemple et al, 1996) impacting their overall academic success. Specifically, findings indicated a positive relation between self-esteem and creativity, and a negative relation between shyness and creativity. Therefore, the link between creativity and selfesteem exists (Kemple et al. 1996).

These empirical works lend evidence that children need the opportunity to engage in creative expression; and that creative expression is important to the development of a positive self-worth. Moreover, theories of multiple intelligences provide justification for a greater role for arts in curriculums (Fowler, 1990). If teachers only gauge children on academics then they have no idea what children can bring to the classroom or what their full potential is. Smolucha (1989) states:

Research on play supports the claim that children learn how to do pretend play through interactions with adults and the interactions effect the development of 
creative imagination. Elkind has pointed out the dangers of imposing formal instruction on pre-kindergarteners in to accelerate learning. (p. 7).

Creativity and academic achievement or success are not one in the same but work together to create a positive academic self-esteem.

\section{Parents 'value of play and creativity}

Studies have shown that many parents place importance on school-related skills over developmentally appropriate practices (Warash, Pelliccionni, \& Yoon, 2000). However, it has been noted that, "Play is perhaps the most important aspect of a young child's life" (Bunker, 1991, p. 467) and is an ideal opportunity for parents to fully engage with their child (Ginsburg, 2007). Further, play works to assimilate experiences in the child's life to broaden their knowledge (Fulmer, 1998). Therefore it seems that parents should promote children's play.

Play and creativity, as promoted by children's parents, leads to higher cognition and greater academic self-esteem. In a study done by Warash and colleagues (2000) parents responded positively to statements in regard to parenting styles. Parents are often more concerned with their child's abilities to read and write as opposed to promoting self-concept (Warash, et al, 2000). Mothers and fathers of 43 children at a major university preschool were surveyed. A survey was created using articles on the developmentally appropriate practice. Developmentally Appropriate Practice in Early Childhood Programs (Bredekamp \& Copple, 2009) defines and describes principles for parents, teachers, policy makers, and others involved with decisions concerning the care and education of young children. Early childhood programs serve children age birth 
through age eight and include child care centers, preschools, and kindergartens (NAEYC). Five dimensions of parenting were assessed through a parental report. The survey included demographic information as well as 20 statements on developmentally appropriate practices for pre-kindergarten curriculum. The Hollingshead Four Factor index of Social Status (1975) was used to establish the social status of the sample. Parents rated statements of developmentally appropriate practice of learning on a scale from one (strongly disagree) to six (strongly agree) (Warash, et al, 2000). The parents responded appropriately, according to the developmentally appropriate practices, stated by the NAEYC, to the questions asked. Parents strongly agreed (82\%) with the statement from the survey that, "Children need to make their own discoveries about the world as they are able to explore materials and learn to play with other children" (Warash, et al, 2000). Many of the parents felt that play is an important tool for learning and that their children need to explore their environment. Parents also indicated that they wanted the best of both worlds for their children; thus, they desired for their children's schooling to include a structured academic program, as well as the ability for their child to learn confidence, self-control, and develop self-esteem. In the same study, teachers also rated the students using the Behavioral Academic Self-esteem. Results indicated that maternal anxiety and guilt were positively correlated with a child's overall academic self-esteem (Warash, et al, 2000). Further they reported consistent parenting styles which influenced play and creativity were positively related to academic self-esteem among daughters. Thus parenting practices can influence children's self-esteem in the classroom.

In another study by Fulmer (1998) parents play interactions with their children and how they felt their children benefited from these experiences were observed Twenty- 
four parents participated in an eight month intervention program which provided a program for enrichment in promoting parental support for their child's exploration in a safe and inspiring environment. The studied consisted of a pre- and post-test using the Level of Parental Awareness (LPA) measure to assess whether discussion of children's play by parents could promote change in their thinking about child development. Parents observed their child's language development, parallel play, choice of play equipment, sex role identification, negotiations, and discipline in a laboratory setting. Once seeing these children interact in the above-noted paradigms, parents began to understand the social and academic aspects relevant to play. Thus it appears that parents can realize the importance for child play and creativity.

\section{Summary}

As noted above, the literature suggests that parents feel that play is important for learning and that children need to explore, however they want their children to be successful academically, regardless of whether standards backed by research on child development are replaced by strict academic standards (Warash et al, 2000). Parents are pressured to have their children succeed academically yet qualities such as self-esteem; confidence, curiosity, and control are best developed through play based learning experiences. Studies show that parents of pre-kindergarten children often have views that are developmentally inappropriate (Warash, et al, 2000). Parents tend to place a higher value on strictly educational values as opposed to promoting a positive self- concept and self-esteem. These parents want their child to be successful even if it compromises standards researched by early childhood educators. In reality, both education and 
developmentally appropriate practices such as play and creativity can be achieved in prekindergarten. However, today many parents feel pressured to have their children become “academic all-stars” (Warash, et al, 2000). In a study on Head Start, Seefeldt, Denton, Gapler, \& Younoszai (1999) found that parent's education and parent's efficacy beliefs were strongly linked to their children's academic abilities. This means that parent's of Head Start children emphasize academics for their child based on their own academic background. Studies of pertaining to Head Start parents' valued and/or emphasis on academics due the pressures of the No Child Left Behind Act can not be found in related research.

Therefore, the following questions seem important to address: (1) Do primary caregivers value play? (2) Do primary caregivers value creativity? (3) Is there a difference in primary caregivers' value of academics versus play? Is there a difference in primary caregivers' value of academics versus creativity? (4) Is there a positive correlation between primary caregivers' endorsement of play and creativity and children's BASE scores? If primary caregivers promote play then in some respect they are likely impacting the academic side of their child, therefore it is expected that primary caregivers who promote play and creativity will have children who are rated to be higher in academic self-esteem. This area of questioning seems significant given that academic self-esteem is believed to be related to academic performance and success. 


\section{Chapter III}

\section{Methods}

Sample

Primary caregivers of pre-school children enrolled at the West Virginia University (WVU) Nursery School in Morgantown, West Virginia were asked to participate. The WVU Nursery School is a child development laboratory for the College of Human Resources and Education, Department of Technology, Learning, and Culture. Morgantown, West Virginia, is approximately 70 miles south of Pittsburgh, Pennsylvania and is located along the Monongahela River in the Appalachian Mountains. Letters were given to the primary caregivers of the children in the two classrooms at WVU Nursery School. Of 36 potential participants, 22 , or $61 \%$, participated in the study.

\section{Participants}

The participants in the study comprised of 22 primary caregivers and two teachers. Of the primary caregivers, 20 were mothers, one was a father, and one was a grandmother. The Parents As A Teacher Inventory (PAAT) was completed on 11 boys and 11 girls. A majority (82\%) of the respondents were Anglo/white, the remaining participants were Asian (9\%) and biracial (9\%). Most participants were married (86\% married , 9\% were separated and 5\% divorced) and had a graduate degree ( $73 \%$ graduate degree, some graduate school $5 \%$, college degree $18 \%$, college degree, $5 \%$ some college no degree). The majority of the participants (86\%) reported income of $\$ 50,000$ or above. 


\section{Procedures}

Primary caregivers were issued a letter (Appendix A) asking for their cooperation in this research study. Primary caregivers who agreed to participate in the study were asked to complete a consent form and the Parents As A Teacher Inventory (Strom, 1984). Information was also gathered from a questionnaire as to the parents' age, sex, income, level of education, occupation, ethnicity, child's sex and age. The numbered questionnaire was completed off-site and returned anonymously to the WVU Nursery School and placed in an envelope. Each questionnaire was numbered corresponding to the number on the Behavioral Academic Self-esteem (BASE) scale (Appendix C), which was completed by the Nursery School Teachers. Children's names and assigned numbers were used on the BASE and the researchers matched them to the corresponding number on the PAAT.

Primary caregivers were asked questions about their own perceptions of their roles as a teacher in regards to what they want and expect from their children (Strom, 1984). Children in each of the two classrooms were observed in the school setting by their teacher using the Behavioral Academic Self-esteem (BASE) Scale (Coopersmith \& Gilberts, 1982).

\section{Measures}

\section{Parents As Teacher Inventory}

The Parents As A Teacher Inventory (PAAT) is a fifty-item parent survey using a likert scale and is a validated standards report on parent's views of what they want or expect from their child. Primary caregivers responded to questions such as "my child 
should be able to make noise during play and it's all right for my child to have a makebelieve friend" with strong yes, yes, no, or strong no (Strom, 1984). The survey of categories were completed by primary caregivers. The PAAT implemented for parents is a cost effective tool and a way to detect impacts parents have on their children.

The PAAT Inventory (Appendix A) was developed for use with mothers and fathers of children between three and nine years old. This assessment is a well functioning tool and requires no additional training to complete. The PAAT is a well established inter-rater-reliability, concurrent and construct validity. The assessment is derived from extensive research on the concept that "appropriate parental expectations are the key to successful childbearing" (Strom, p.1, 1984). The main objective of the PAAT Inventory is to help teachers better understand cultural and parental differences in regard to parenting and child behaviors (Strom, 1984). The PAAT Inventory yields five factors: creativity, frustration, control, play, and teacher-learning. The creativity factor assesses parent's encouragement or lack of in their child's activity. Frustration assesses parents' ways of dealing with children and the control factor rates how child behavior is dealt with if necessary by the parents. The play factor aims to address the parents' influence and understanding of play. The fifth factor is teaching- learning which gauges parents' ideas on how their roles influence their child's learning.

With the current sample, Cronbach's Alpha was computed to assess reliability of the factors; for each factor items were excluded if reliability was improved with their deletion. The following reliabilities were yielded: Creativity $(\alpha=.63 ; 1$ item (26) excluded from the subscale), frustration ( $\alpha=.57 ; 1$ item (42) excluded from the subscale), control $(\alpha=.71)$, play ( $\alpha=.71 ; 1$ item (4) excluded from the subscale), teaching/ learning 
$(\alpha=.64 ; 1$ item (25) excluded from the subscale, academics $(\alpha=.39 ; 2$ items $(51,52)$ were excluded from the subscale.

The subscales were computed following Strom (1984). Specifically mean scores were computed to yield six subscales: Creativity, frustration, control, play, and teaching/ learning. This study used the play and creativity subscales.

An additional sixth factor was created based on Warash et al. (2000) to assess primary caregiver's beliefs about the importance of academics in preschool. Specifically, four items were added (e.g., "Children should not be hurried nor should they be made to wait for extended periods of time") to assess primary caregivers value of academics.

\section{Behavioral Academic Self-esteem}

Children in each of the two classes, upon approval from their primary caregiver, were assessed by teachers using the Behavioral Academic Self-Esteem (BASE) (see Appendix C) Scale which looks at “children's academic self-esteem by using direct observation in their classrooms" (Coopersmith \& Gilberts, p. I-1, 1982). Children were observed completing tasks based on 16 items over a few minutes.

Assessments of the children using the BASE were conducted at the WVU Nursery School by the lead teachers for each class. In order to use the BASE teachers are required to have at least five to six weeks of classroom experience with children. All children were between the ages of three and five.

Teachers rated academic self-esteem using a five point scale including answers of never, seldom, sometimes, usually, and always. Categories were established by Coppersmith's theory and developed to "infer self-esteem from observations of 
behaviors" (Coopersmith \& Gilberts, p. I-1, 1982). Categories included in this measure are: student initiative (e.g. "the child tasks on new tasks"), social attention (e.g." the child cooperates with others"), success/ failure (e.g. "the child deals with mistakes easily"), social attraction (e.g. "the child refers to himself/ herself in positive terms"), and selfconfidence (e.g. "the child readily expresses opinions" ), BASE total (e.g. combination of all student initiative, social attention, success/ failure, social attraction, and self confidence) .

With the current sample, Cronbach's Alpha was computed to assess reliability of the factors. The following reliabilities were yielded: student initiative $(\alpha=.93)$, social attention $(\alpha=.68)$ success/failure $(\alpha=.90)$, social attraction $(\alpha=.84)$, self-confidence $(\alpha=$ $.89)$, BASE Total $(\alpha=.94)$.

The subscales were computed following Coopersmith \& Gilberts (1982). Specifically mean scores were computed to yield six subscales: student initiative, social attention, success/ failure, social attraction, self-confidence, and the total BASE score. 


\section{Chapter IV}

$$
\text { Results }
$$

\section{Descriptives}

First descriptive statistics were computed for all variables and are presented in

Table 1. A majority ( $82 \%$ ) of the respondents (primary caregivers) were Anglo/white, as well most were married (86\%), and had a graduate degree $(73 \%)$. The majority of the participants $(86 \%)$ reported income of $\$ 50,000$ or above.

Table 1

Means and Standard Deviations

Variable

PAAT

Creativity

Frustration

Control

Play

Teaching/Learning

Academics

BASE

Student Initiative

Social Attention

Success/Failure

Social Attraction

Self-confidence

BASE Total

$\begin{array}{ccccc}M & \text { SD } & \text { Min } & \text { Max } & N \\ & & & & \\ 3.04 & .33 & 2.33 & 3.67 & 22 \\ 2.09 & .29 & 1.67 & 2.56 & 22 \\ 2.18 & .34 & 1.40 & 2.70 & 22 \\ 3.11 & .33 & 2.44 & 3.67 & 22 \\ 3.27 & .29 & 2.67 & 3.67 & 22 \\ 2.70 & .67 & 2.00 & 4.00 & 22\end{array}$

$\begin{array}{lllll}4.28 & .65 & 3.00 & 5.00 & 20 \\ 4.13 & .61 & 3.00 & 5.00 & 20 \\ 3.88 & .76 & 2.00 & 5.00 & 20 \\ 4.15 & .86 & 2.67 & 5.00 & 20 \\ 4.55 & .61 & 3.50 & 5.00 & 20 \\ 4.21 & .58 & 3.06 & 5.00 & 20\end{array}$

In addition bivariate correlations were computed for the subscales for the Parents As A Teacher Inventory (PAAT) and the Behavioral Academic Self-esteem (BASE) and are represented in Table 2. A significant relationship was found between frustration and control $(r=.540)$, creativity and play $(r=.551)$, student initiative and social attention $(r=$ $.684)$, student initiative and success/ failure $(r=.608)$, student initiative and social attractiveness $(r=.712)$, student initiative and self confidence $(r=.568)$, social attention and success/ failure $(r=.820)$, social attention and social attractiveness $(r=.643)$, and success/ failure and social attractiveness $(r=.621)$. It makes sense that each of these 
subscales would be positively related as they conceptually tap into the aspect of high selfesteem. Significant negative relationships were found between creativity and frustration $(r=-.646)$, creativity and control $(r=-.529)$, frustration and play $(r=-.562)$, frustration and teaching/learning $(r=-.550)$, control and play $(r=-.652)$, and control and teaching/learning $(r=-.581)$. There fore lending evidence for discriminate validity.

Table 2 -

Correlations

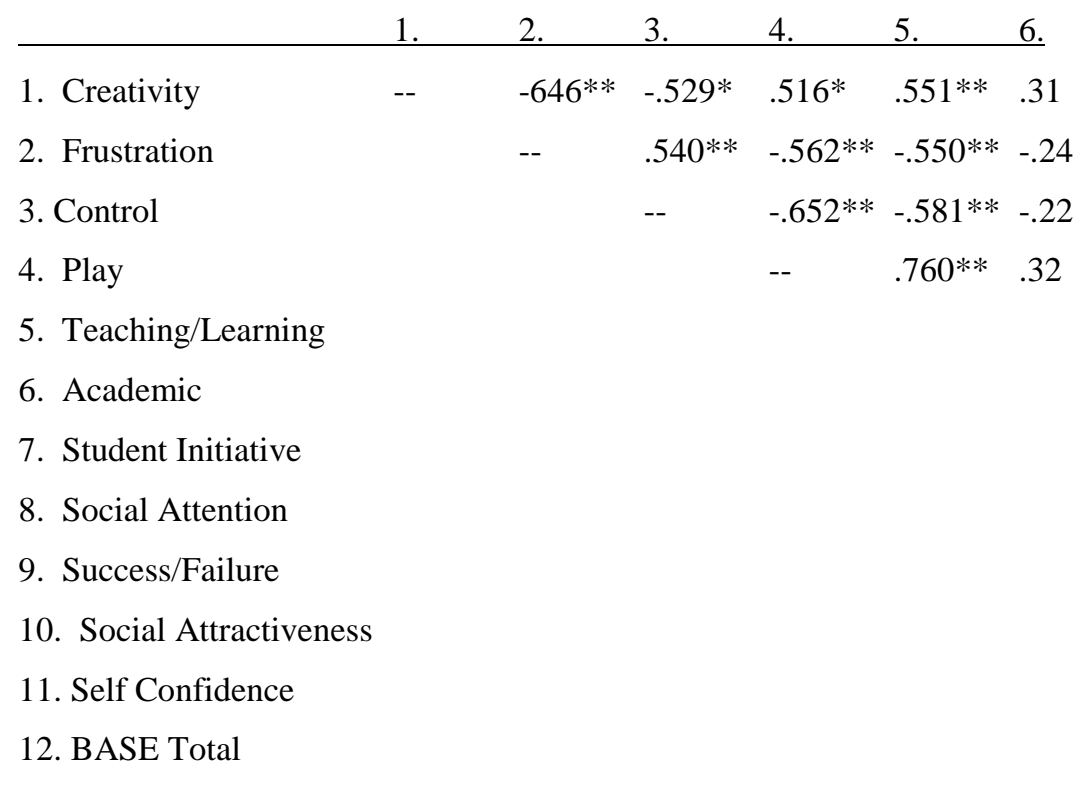

$* p<.05 ; * * p<.01(2$-tailed $)$

Table 2 - continued

Correlations

\begin{tabular}{lllllll}
\hline & 7. & 8. & 9. & 10. & 11. & 12. \\
1. Creativity & -.032 & .130 & .076 & .033 & .038 & .04 \\
2. Frustration & .178 & .030 & .138 & -.044 & .047 & .10 \\
3. Control & .184 & .116 & .187 & .219 & .091 & .20 \\
4. Play & .026 & .112 & -.089 & -.086 & .440 & .05 \\
5. Teaching/Learning & -.186 & .043 & -.036 & -.066 & .225 & -.07 \\
6. Academic & .21 & .17 & 28 & .20 & .26 & .26 \\
7. Student Initiative & -- & $.684^{* *}$ & $.608^{* *}$ & $.712^{* *}$ & $.568^{* *}$ & $.93^{* *}$
\end{tabular}



8. Social Attention
$-\quad .820$
$.820^{* *} \quad .643 * * \quad .388 \quad .85^{* *}$
9. Success/Failure
$--\quad .621 * * \quad .072 \quad .76^{* *}$
10. Social Attractiveness
$--\quad .389 \quad .86^{* *}$
11. Self Confidence
$--.57^{* *}$
12. BASE Total

- $\quad p<.05 ; * * p<.01$ (2-tailed)

Analysis

Research Question \#1: Do primary caregivers value play?

As depicted in Figure 1, it appears that primary caregivers value play $(M=3.11)$ at similar levels as they endorse creativity $(M=3.04)$, but higher than academics $(M=$ 2.70).

Figure 1

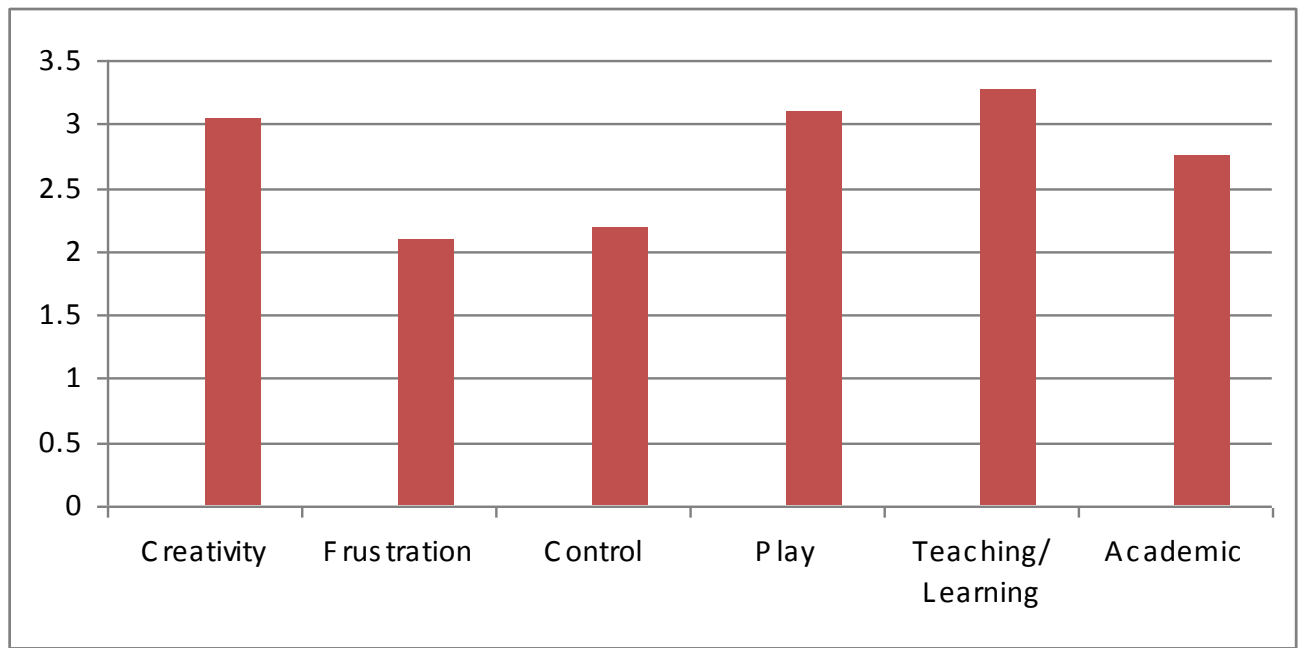

Research Question \#2: Do primary caregivers value creativity?

Also depicted in Figure 1, it appears that primary caregivers value creativity $(M=$ 3.04) at similar levels as they endorse play $(M=3.11)$, but higher than academics $(M=$ 2.70). 
Research Question \#3: Is there a difference in primary caregivers' value of academics versus play? Is there a difference in primary caregivers' value of academics versus creativity?

To test research question \#3, paired samples $t$ tests were computed. There was a significant difference in primary caregivers endorsement of play $(\mathrm{M}=3.11)$ and academics $(\mathrm{M}=2.70)(t(21)=-2.96, p<.05)$, and creativity $(\mathrm{M}=3.04)$ and academics $(\mathrm{M}=2.70)(t(21)=-2.41, p<.05)$ and creativity $(\mathrm{M}=3.04)$. Therefore, primary caregivers feel that play helps their child develop more than academics overall.

Research Question \#4: Is there a positive relation between primary caregivers' endorsement of play and creativity and children's BASE scores?

To test research question \#4, linear regression analyses were computed. Primary caregivers' PAAT scores for play, creativity and academics were entered as predictor variables to the BASE subscales: student initiative, social attention, success/failure, social attractiveness, self confidence, and BASE Total. Therefore a total of six regression analyses were computed. The only regression analyses found to be significant was the prediction of self-confidence. Specifically, primary caregivers' endorsement of play was a significant predictor of teacher's ratings of children's self-confidence in the classroom $\left(R^{2} \Delta=.21 ; F \Delta=4.64 ; p<.05\right)$. The presence of a positive beta weight $(\beta=.50)$ indicated that primary caregivers that endorsed high levels of play had children who were reported to have high self-confidence. Therefore, parents who allow their children to spend a great amount of time in play have children who are more self confident overall. 
Table 3

Regression analyses predicting BASE

\begin{tabular}{|c|c|c|c|c|c|c|c|c|c|}
\hline \multirow[b]{2}{*}{ Predictors } & \multicolumn{3}{|c|}{ Social Initiative } & \multicolumn{3}{|c|}{ Social Attention } & \multicolumn{3}{|c|}{ Success/Failure } \\
\hline & $\mathrm{R}$ & $\Delta \mathrm{R}^{2}$ & $\beta$ & $\mathrm{R}$ & $\Delta \mathrm{R}^{2}$ & $\beta$ & $\mathrm{R}$ & $\Delta \mathrm{R}^{2}$ & $\beta$ \\
\hline Creativity & .03 & .001 & -.03 & .130 & .017 & .130 & .076 & .006 & .076 \\
\hline Play & .05 & .002 & .05 & .146 & .004 & .072 & .149 & .017 & -.140 \\
\hline Academic & .23 & 0.05 & .23 & .20 & .02 & .14 & .33 & .09 & .31 \\
\hline
\end{tabular}

Table 3 - continued

Regression analyses predicting BASE

\begin{tabular}{lcccccccccc}
\hline & \multicolumn{3}{l}{ Social Attractiveness } & \multicolumn{2}{c}{ Self- Confidence } & \multicolumn{2}{c}{ BASE Total } \\
Predictors & $\mathrm{R}$ & $\Delta \mathrm{R}^{2}$ & $\beta$ & $\mathrm{R}$ & $\Delta \mathrm{R}^{2}$ & $\beta$ & $\mathrm{R}$ & $\Delta \mathrm{R}^{2}$ & $\beta$ \\
\hline Creativity & .033 & .001 & .033 & .038 & .001 & .038 & .04 & .002 & .04 \\
Play & .113 & .012 & -.117 & .464 & .214 & $.503 *$ & .06 & .002 & .04 \\
Academic & .24 & -.05 & .23 & .50 & .03 & .18 & .26 & .06 & .26
\end{tabular}




\section{Chapter V}

\section{Discussion}

\section{Interpretation of Results}

The purpose of this research study was to investigate the primary caregiver's value of play and creativity as it relates to their preschool child's academic self-esteem. Parent's values of play and creativity were measured by the Parents As A Teacher Inventory (PAAT) and the teacher's ratings of the child's academic self-esteem as measured by the Behavioral Academic Self-esteem (BASE) Scale. The following questions were addressed: (1) Do primary caregivers value play? (2) Do primary caregivers value creativity? (3) Is there a difference in the primary caregivers' value of academics and the value of play? Is there a difference in the primary caregivers' value of academics and the value of creativity? (4) Is there a positive correlation between primary caregivers' value of play and creativity and children's scores on the subsets of the BASE as well as the total BASE score? Base subsets included: student initiative, social attention, success/failure, social attractiveness, and self confidence.

In this study, primary caregivers valued play, as measured on the PAAT Inventory. This is similar to the findings of Warash et al. (2000) in that parents feel that play is an important learning tool and that children need to explore their environment. Ginsburg (2007) stated that parents in today's society are too fast paced, going from one activity to the next. Every aspect of a child's day is structured allowing no time for free play which would lead to the de-emphasis on play. Primary caregivers in this study recognize the value of play according to their responses on the PAAT. As indicated from 
the PAAT, the parents allow their child to engage in such unstructured activities. Fulmer (1998) also found that parents began to understand the social and academic aspects relevant to play. Thus, it appears that primary caregivers realize the importance for child play.

It was also revealed that primary caregivers valued creativity as demonstrated on the PAAT. Gardner (1983) and Torrance (1974) stressed that children's creative expression is a way of promoting academic self-esteem in early childhood and that children should be free and able to be creative and expressive. Kemple and colleagues (1996) also found that there was a positive relation between self-esteem and creativity. Play and creativity go hand in hand, each accentuates the other. If primary caregivers' value play it would only make sense that they also place value on creativity. The creative aspect is often missing from a child's overall development due to the demands for academics and accountability in schools. Young children are often unable to spend quality time engaging in open expression through a creative means. This finding, that primary caregivers' value creativity, indicates a positive step in the right direction. If parents, school administrators, and policy makers work together children may be able to express themselves more freely in turn which may impact their overall academic performance.

Primary caregivers in this study valued both play and creativity more than academics. This is a surprising finding considering the emphasis on the push for young children to succeed in school. The current study reiterates the findings of Warash et al. (2000) in that parents value play and creativity more than academics. Parents feel that play is an important tool for learning and that their children need to explore their 
environment. As Warash et al. (2000) indicated parents often wanted the best of both aspects for their children; thus, they desired for their children's schooling to include a structured academic program, as well as the ability for their child to learn confidence, self-control, and develop a positive self-esteem. Primary caregivers at the WVU Nursery School, where the research was conducted, endorsed play and creativity over academics. In this study primary caregivers who valued play also had children who were high in the subset of self- confidence on the BASE. Self confidence as rated on the BASE is the child's verbal expression about school accomplishment via opinions, assessment, and expectations about present and future performance. Children that are rated high in selfesteem are usually rated high in self- confidence (Coopersmith \& Gilberts, 1982). Bunker (1991) also found that play and self confidence are related. Children who are able to play and learn to cope, problem solve, and communicate through these experiences develop a better sense of self and thus are more confident over all. This finding also aligns with the results of Warash and Markstrom's (2001) investigation of parents' involvement with their children and school performance and confidence. These findings support the current study in that a majority of the primary caregivers (mothers) value of play and creativity had an impact on their child's academic self-esteem. All other subsets of the BASE, including student initiative, social attention, success/failure, social attractiveness, and the BASE total were found to be insignificant when related to play, creativity, and academics.

In essence, primary caregivers rated play as an important component in their child's lives. In addition, play contributed to the subset of self-confidence (7) from the BASE. Vygotsky (1978) was one who theorized that mature play assisted children to 
self- regulate their behavior. This is an important component for later school success. Gardner (1983) and Piaget (1962) expressed that they feel that young children should be children, free and open to the opportunity to indulge in play and creative expression. Play is how children grow cognitively. As well, creativity or the process of thinking and responding to experiences and stimuli (Isenberg \& Jalongo, 1997) impacts later school success. In addition, the process of sensing problems or gaps in information as well as forming ideas or hypotheses, testing and modifying these hypotheses, and communicating the results, all aspects of creativity described by Torrance (1974), accentuate the self system and school success

The importance of play on a child's academic self-esteem does not align with the ideas of the No Child Left Behind Act (2001) which places such a strong emphasis on accountability in academics while neglecting other important aspects of a child's overall development. However, as previously stated the interaction that occurs in play goes hand in hand with creativity and produces a better environment for children to pursue academics. Play is a significant factor in the development of a child's self confidence thus they should engage in all forms of play regularly

It is surprising that the primary caregivers' value of creativity on the PAAT was not a significant predictor of self confidence or any of the subsets on the BASE completed by the teachers. Little information is known about the value primary caregivers' place on creativity; more is known about the value of play. However, this is surprising due to the fact that play and creativity go hand in hand. 


\section{Limitations}

This study found some interesting findings however there were numerous limitations. A small sample size as indicated in the results is a shortcoming. These findings cannot be generalized beyond this sample. The Parent As A Teacher Inventory (PAAT) was a self report measure. Self reporting may contain some bias. Primary caregivers, especially from this population, may have known how to answer the questions to get the feedback the researcher was seeking. These primary caregivers have a social desire to have their children engage in play and promote learning. They have the abilities to allow these kinds of interaction to occur. Another aspect impacting the results of the study may include the socio economic status of the families. A majority of the families studied were middle- class which may have impacted their endorsement of play and creativity in relation to their child's academic self-esteem. In addition these primary caregivers were related to the university community and were oriented to the preschool philosophy of play which may be reason for choosing this school for their child. The WVU Nursery School, where the study was conducted, endorses play and the aspects of creativity through its own curriculum, as well as the Creative Curriculum by Dodge, Colker, and Heroman (2002). Parents at the school are well versed about play from the emphasis the school places on play.

\section{Future Directions}

Few studies have looked at the impact of the specific element of academic selfesteem in relation to play and creativity. Academic self-esteem is a specific form of selfesteem which is observed in the classroom setting, and can be reflected in how children 
become effective in exploration and dealing with change in their environment (Coopersmith \& Gilberts, 1982). Flouri (2006) states that few studies have addressed the mothers' interests in children's education as they are linked to their children's selfesteem. Further research needs to be conducted to indicate the exact aspects of play which impact the development of self confidence and the other subsets of the BASE. In addition, other measures need to be used to find the impact of play and creativity, alone and together, on the overall development of self. A large and more diverse sample size would help obtain a more generalizable information to the research questions proposed in this study. It would be good to address every socioeconomic status, varying races/ ethnicities, and different types of schools which may use various academic based curriculums.

\section{Conclusion}

Play and creativity are crucial aspects in child development. Every domain in child development is addressed through play and creativity. National leaders and policy makers need to evaluate their decisions and account for the whole child and realize that academics can be strengthened by play. This can be done if everyone works together. School can still be accountable and benefit children when they allow them to play and be creative individuals. Overall, learning through play and creativity allow the child to have a better sense of self and a better foundation for academics. As theorists have stated, play is a primary learning tool for children (e.g., Elkonin, 1978; Parten, 1932; Piaget, 1962, Vygotsky, 1978). 
Overall the No Child Left Behind Act (2001) is aimed at promoting academic accountability and student learning. However, they failed to acknowledge the vital learning that occurs through play. This neglect has lead early childhood education teachers to engage in practices that contradict theorists in the field in order to obtain and keep accountability. National leaders need to work with early childhood educators to create legislation that promotes theological based educational practices. 


\section{References}

Amatea, E. S. (2009). Building Culturally Responsive Family-School Relationships. University of Florida: Merrill.

Bodrova, E., \& Leong, D. J. (2003). Chopsticks and counting chips. Young Children, $58(3 ; 3), 10-17$.

Bodrova, E., Leong, D. J., Hensen, R., \& Henninger, M. (2000). Imaginative, childdirected play: Leading the way in development and learning. Dimensions of Early Childhood, 28(4), 25-30.

Bredekamp, S., \& Copple, C. (Eds.). (2009). Developmentally Appropriate Practice in Early Childhood Programs Serving Children From Birth Through Age 8 ( $3^{\text {rd }}$ ed.). Washington, D.C., U.S.A.: Natl Assn for the Education.

Bunker, L. K. (1991). The role play and motor skill development in building children's self-confidence and self-esteem. Elementary School Journal, 91(5; 5), 467.

Case, R. (1998). The development of central conceptual structures. In W. Damon (Editor-in-chief) \& D. Kuhn \& R. S. Siegler (Vol. Eds.), Handbook of Child Psychology: Vol. 2. Cognition, perception, and language (5th ed., pp. $745-800$ ). New York: Wiley.

Cast, A. D., \& Burke, P. J. (2002). A theory of self-esteem. Social Forces, 80(3), 10411068. 
Coopersmith, S. \& Gilberts, R. (1982) Behavioral Academic Self-Esteem (BASE) Manuel. Palo Alto, CA. Consulting Psychologist Press

Cornett, C.E. (2003). Creating Meaning through Literature and the Arts: An Integration Resource for Classroom Teacher. (2nd ed.). Upper Saddle River, New Jersey: Merrill Prentice Hall.

Dickstein, E. (1972) The Development of self-esteem: Theory and measurement. Unpublished doctoral dissertation, The Johns Hopkins University.

Dodge, D., Colker, L., \& Heroman, Cate. (2002). The Creative Curriculum (4th ed.). Washington, D.C.: Teaching Strategies, Inc.

Drew, W. F., Christie, J., Johnson, J. E., Meckley, A. M., \& Nell, M. L. (2008). Constructive play. Young Children, 63(4; 4), 38-44.

Elkind, D. (1989). Developmentally appropriate education for 4-year-olds. Theory into Practice, 28(1), 47.

Elkonin, D. (1978). Psikhologija igry [The psychology of play]. Moscow: Pedagogika

Entwisle, D. R., Alexander, K. L., Pallas, A. M., \& Cadigan, D. (1987). The emergent academic self-image of first graders: Its response to social structure. Child Development, 58(5), 1190-1206. 
Finn, C., (2008). Voluntary Pre-Kindergarten. Retrieved October 30, 2008, from http://www.teachmorelovemore.org/PDF/ktf_florida_book_229.pdf

Flouri, E. (2006). Parental interest in children's education, children's self-esteem and locus of control, and later educational attainment: Twenty-six year follow-up of the 1970 british birth cohort. British Journal of Educational Psychology, 76(1), 41-55.

Fowler, C. (1990). Recognizing the role of artistic intelligences. Music Educators Journal, 77(1), 24-27.

Fulmer, K. A. (1998). Cued observation and discussion of young children's play: Promoting change in parental thinking and reasoning about child development. International Journal of Early Years Education, 6(3), 253.

Frost, J., Wortham, S., \& Reifel, S. (2005). Play and child development. Upper Saddle River, New Jersey: Pearson Prentice Hall.

Gaffield, C. (1994). Children's lives and academic achievement in Canada and the United States. Comparative Education Review, 38(1), 36-64.

Gardner, H. (1983). Frames of mind: The theory of multiple intelligences. New York: Basic Books. 
Gerrard, L. E., Poteat, G. M., \& Ironsmith, M. (1996). Promoting children's creativity: Effects of competition, self-esteem, and immunization. Creativity Research Journal, 9(4), 339.

Ginsburg, K. R. (2007). The importance of play in promoting healthy child development and maintaining strong parent-child bonds. clinical report. Pediatrics, 119(1), 182191.

Gronlund, G., \& Koralek, D. (2008). Standards, standards everywhere! Young Children, 63(4), 10-13.

Gross, D. (2008). Infancy: Development from Birth to Age. Boston, MA: Pearson Education, Inc.

Harris, P. L. (2000). The work or the imagination. Oxford: Blackwell.

Helm, J. H. (2008). Got standards?: Don't give up on engaged learning! (cover story). Young Children, 63(4; 4), 14-20.

Hewett, V. M. (2001). Examining the reggio emilia approach to early childhood education. Early Childhood Education Journal, 29(2), 95-100.

Hollingshead, A. (1975) The Four Factor Index of Social Status. New Haven, CT: Yale University. 
Innovations (2004) New “Tools of the Mind” Curriculum Aims To Boast Memory, SelfControl, and Literacy. Innovations. 5-9

Isenberg, J.P., \& Jalongo, M. (1997). Creative Expression and Play in Early Childhood. (2nd ed.) Upper Saddle River, New Jersey: Prentice- Hall.

Izard, C. (2002) Emotion Knowledge and Emotion Utilization to Facilitate School Readiness. Social Policy Report: Giving Child and Youth Development Knowledge Away. Volume XVI, Number 3. 7-11.

Johnson, J.E., Christie, J.F., \& Wardle, F. (2005). Play, Development, and Early Education. Boston, Massachusetts: Pearson.

Johnson, J.E., Christie, J.F., \& Yawkey, T.D. (1999). Play and Early Childhood Development. (2nd ed.). Reading, Massachusetts: Longman.

Kemple, K. M., David, G. M., \& Yiping Wang. (1996). Preschoolers' creativity, shyness, and self-esteem. Creativity Research Journal, 9(4), 317.

Lindqvist, G. (2003). Vygotsky's theory of creativity. Creativity Research Journal, 15(2), 245.

Logue, M. E. (2007). Early childhood learning standards: Tools for promoting social and academic success in kindergarten. Children \& Schools, 29(1), 35-43. 
McAfee, O. \& Leong, D.J. (2007). Assessing and guiding young child development and learning $\left(4^{\text {th }}\right.$ ed. $)$. Boston, MA: Merrill.

Parten, M. (1932). Social participation among pre-school children. Journal of Abnormal and Social Psychology, 27, 243-269.

Piaget, J. (1962). Play, dreams, and imitation in childhood. New York: Garland.

Pellegrini (2008). Journal of American Play fall 2008, page181-191 volume 1, no.2)

Peller, L. (1952). Models of children's play. Mental Hygiene, 36, 6643.

Raver, C.C. (2002). Emotions Matter: Making the Case for the Role of Young Children's Emotional Development for Early School Readiness. Social Policy Report: Giving Child and Youth Development Knowledge Away. Volume XVI, Number 3. 3-7.

Rogers, C.R. (1954). Towards a theory of creativity. ETC. A Review of General Semantics, $11,249-260$

Rogers, C. \& Sawyer, J. (1988). Play in the lives of children. Washington, D.C.: NAEYC.

Ross, C. E., \& Broh, B. A. (2000). The roles of self-esteem and the sense of personal control in the academic achievement process. Sociology of Education, 73(4; 4), 270284. 
Rubin, K. H. (2008). The play observation scale. Unpublished coding taxonomy: University of Maryland, College Park.

Ryan, R. M., Stiller, J. D., \& Lynch, J. H. (1994). Representations of relationships to teachers, parents, and friends as predictors of academic motivation and self-esteem. Journal of Early Adolescence, 14(2; 2), 226-249.

Scarlett, W.G, Naudeau, S., Salonius- Pasternak, D., \& Ponte, I. (2005). Children's Play. Thousand Oaks, California: Sage.

Schiller, P. \& Willis, C. (2008). Using brain- based teaching strategies to creative supportive early childhood environments that address standards. Young Children, $63(4 ; 4), 52-55$.

Seefeldt, C., Denton, K., Gapler, A., \& Younoszai, T. (1999) The relation between parents' participation in a transition demonstration, education, efficacy, and their children's academic abilities. Early Childhood Research Quarterly, 12, No.1, 99109.

Singer, I.L. (1973). The child's world of make believe: Experimental studies of imaginative play. New York: Academic Press.

Smolucha, F. (1989). The relevance of vygotsky's theory of creative imagination for contemporary research on play. 
Strom, R. \& Slaughter, H (1978). Measurement of childrearing expectations using The Parent As A Teacher Inventory. Journal of Experimental Education, 46. 44-53

Strom, R.D. (1984) Parent As A Teacher Inventory Manual. Bensenville, IL. Scholastic Testing Service.

Sylvan Learning, (2008). Retrieved November 1, 2008, from http://tutoring.sylvanlearning.com/pre_k_tutoring.cfm

Torrance, E.P. (1974). The Torrance Test of Creativity Thinking; norms- technical manual. Lexington, Mass.: Personnel Press.

Torrence, M. (2001). Montessori and play: Theory vs. practice. Montessori Life, 13(3; 3), $8-11$.

U. S. Department of Education (2005). Facts and terms every parent should know about NCLB. Retrieved December 28, 2008 from http://www.ed.gov/nclb/overview/intro/parents/parentfacts.html

Van Hoorn, J., Nourot, P., Scales, B., \& Alward, K. (2003). Play at the center of the curriculum. Uppers Saddle River, New Jersey: Pearson.

Vygotsky, L.S. (1978). Mind in Society: The development of higher mental processes. Cambridge, MA: Harvard University Press. 
Wagner, B. M., \& Phillips, D. A. (1992). Beyond beliefs: Parent and child behaviors and children's perceived academic competence. Child Development, 63(6), 1380-1391.

Warash, B. G., \& Markstrom, C. A. (2001). Parental perceptions of parenting styles in relation to academic self-esteem of preschoolers. Education, 121(3), 485.

Warash, B., Pelliccioni, M., \& Yoon, D. (2000). The views of middle-class parents on developmentally appropriate practice. Leadership Quest, 8-11.

West Virginia Department of Education. (2005). West Virginia Board of Education continues to strengthen early childhood education. Retrieved October 182008 from http://wvde.state.wv.us/news/1029/.

West Virginia Department of Health and Human Resources. (2003). West Virginia Pre-k Approved Curricula. Retrieved October 182008 from http://www.wvdhhr.org/oss/pieces/ta/documents/curriculalistdec03.pdf

West Virginia Early Learning Standards Framework. (2003). In West Virginia Department of Health and Human Resources. Retrieved from West Virginia Early Learning Standards Framework: http://www.wvdhhr.org/bcf/ece/earlycare/stateplan/07_09_attachments/Attachme nt_5.2_WVELSF.pdf

Youngblade, L.M., \& Dunn, J. (1995). Individual differences in young children's 
pretend play with mother and siblings: Links to relationships and understanding of other people's feelings and beliefs. Child Development, 66, 1472-1492. 
Appendix A

\section{Letter}




\title{
Whest VirginiaUniversity. \\ Office of Research Compliance
}

\section{CONSENT AND INFORMATION FORM}

\author{
OMR ICF - PARENT FORMS
}

Principal Investigator: Warash, Barbara

Department: HUMAN RESOURCES \& EDUCATION - Technology,

Tracking Number: Learning, and Culture (TLC)

$\mathrm{H}-21631$

Study Title:

Primary Caregivers' Values of Play and Creativity in Early Childhood in Relation to Children's Academic Self-Esteem

Co-Investigator(s):

Martino, Jill,Kennedy, Amy,

Sponsor

\section{Contact Persons}

If you have any questions, concerns, or complaints about this research, you can contact Dr. Bobbie Warash at 304/293-2110.

For information regarding your rights as a research subject, you may contact the Office of Research Compliance at 304/293-7073.

\section{Introduction}

You, , have been asked to participate in this research study, which has been explained to you by Dr. Bobbie Warash, Ed.D. This study is being conducted by Dr. Bobbie Warash,Ed.D., Dr. Amy KennedyRoot,Ph.D., and Jill Martino B.S. in the Department of Technology, Learning, and Culture at West Virginia University. This research is being conducted to fulfill the requirements for a Master's thesis in Educational Psychology in the Department of Technology, Learning and Culture at West

\begin{tabular}{lllll}
\hline Tracking \#: & H-21631 & Page 1 of 5 & \\
Approved On: & $04 / 21 / 2009$ & & & Date \\
Valid Through: & $04 / 20 / 2010$ & & \\
Last Amended: & N/A & & & \\
\end{tabular}


Tracking \#: $\quad \mathrm{H}-21631$

Virginia University, under the supervision of Dr. Bobbie Warash, Ed.D.

\section{Purposes of the Study}

The purpose of this study is to examine four research questions: (1) Do caregivers value play? (2) Do caregivers value creativity? (3) Is there a difference in primary caregivers value of academics versus primary caregivers value of play and creativity? and (4) Is there a positive relation between primary caregivers' endorsement of play and creativity and children's academic self-esteem (i.e., favorable impression of one's self, or how your child feels about him/herself in relation to academics)? You have been invited to participate in this research study which involves primary caregivers views on play, creativity, and academics in relation to self-esteem (see definition above). The purpose of this study is to evaluate any relationship between primary caregivers' endorsement of play and creativity and children's academic self-esteem. WVU expects to enroll approximately 38 subjects.

\section{Description of Procedures}

This study involves an examination of primary caregivers' beliefs about how children should be taught at the preschool level and the subsequent relations with children's academic self-esteem exhibited in the classroom and will take approximately one 20-minute period for you to complete.

Specifically, you will be asked to fill out a questionnaire regarding parents views on different teaching practices. This will take approximately 20 minutes. You do not have to answer all the questions. You will have the opportunity to see the questionnaire before signing this consent form.

In addition, teachers will complete an observation of your child's selfesteem in the classroom, this is a regular educational practices. However, it is important for you to know that your answers on the questionnaire you complete (PAAT) will be compared with the observations the teachers make about your child's feelings of academic self-esteem.

\section{Risks and Discomforts}

There are no known or expected risks from participating in this study, except for the mild frustration associated with answering the questions.

\begin{tabular}{lllll}
\hline Tracking \#: & $\mathrm{H}-21631$ & Page 2 of 5 & \\
Approved On: & $04 / 21 / 2009$ & & & Initials \\
Valid Through: & $04 / 20 / 2010$ & & \\
Last Amended: & N/A & & &
\end{tabular}


Tracking \#: $\quad \mathrm{H}-21631$

\begin{abstract}
Alternatives
You do not have to participate in this study.

Alternatives that could be considered in your case include not participating in the study.

\section{Benefits}

You may not receive any direct benefit from this study. The knowledge gained from this study may eventually benefit others. Possible benefits that may result from your participation include a better understanding of how caregivers contribute to their preschoolers' academic self-esteem. The knowledge gained from this study may eventually benefit others in the larger community with a better understanding of how caregivers can contribute to their children's academic self-esteem via stressing play and creativity.
\end{abstract}

\title{
Financial Considerations
}

There is no cost to participate in the study. Participants will not be paid, given class credit, or otherwise rewarded for partipation.

\section{Confidentiality}

Any information about you that is obtained as a result of your participation in this research will be kept as confidential as legally possible. Your research records and test results, just like hospital records, may be subpoenaed by court order or may be inspected by federal regulatory authorities without your additional consent. In addition, there are certain instances where the researcher is legally required to give information to the appropriate authorities. These would include mandatory reporting of infectious diseases, mandatory reporting of information about behavior that is imminently dangerous to you or to others, such as suicide, child abuse, etc. In any publications that result from this research, neither your name nor any information from which you might be identified will be published without your consent. You will be given a cover letter describing the study protocol. If you wish to participate and all questions about the protocol have been answered, you will complete this consent form to sign and return to the envelope in the Nursery School with your questionnaire.

\begin{tabular}{lll}
\hline Tracking \#: & $\mathrm{H}-21631$ & Page 3 of 5 \\
Approved On: & $04 / 21 / 2009$ & \\
Valid Through: & $04 / 20 / 2010$ & \\
Last Amended: & N/A &
\end{tabular}


Tracking \#: $\quad \mathrm{H}-21631$

Again, if you choose not to participate, there will be no penalty to you or your child. The director of the WVU Nursery School will not be given information about participants.You will be assigned an identification number. The numbered questionnaire will be completed off-site and returned anonymously to the WVU Nursery School. Each questionnaire will be numbered corresponding to the number on the Academic Self Esteem (BASE). Names will not be used.

\section{Voluntary Participation}

Participation in this study is voluntary. You are free to withdraw your consent to participate in this study at any time. Refusal to participate or withdrawal will not affect your future care, privileges, or opportunities at the WVU Nursery School, and will involve no penalty to you. In the event new information becomes available that may affect your willingness to participate in this study, this information will be given to you so that you can make an informed decision about whether or not to continue your participation. You have been given the opportunity to ask questions about the research, and you have received answers concerning areas you did not understand.Participants will only be contacted once to complete the questionnaires. If participants refuse, they will not be contacted again. Further participants, who do not responded, will only be followed-up once to confirm receipt of the recruitment letter.

\begin{tabular}{lll}
\hline Tracking \#: & $\mathrm{H}-21631$ & Page 4 of 5 \\
Approved On: & $04 / 21 / 2009$ & \\
Valid Through: & $04 / 20 / 2010$ & \\
Last Amended: & N/A &
\end{tabular}


Upon signing this form, you will receive a copy.

I willingly consent to participate in this research.

$\begin{array}{llll}\begin{array}{l}\text { Signature of Subject or } \\ \text { Subjects Legal Representative }\end{array} & \text { Date } & \text { Time }\end{array}$

The participant has had the opportunity to have questions addressed. The participant willingly agrees to be in the study.

$\begin{array}{llll}\begin{array}{l}\text { Signature of Investigator or } \\ \text { Co-Investigator }\end{array} & \text { Drinted Name } & \text { Time }\end{array}$

\begin{tabular}{lllll}
\hline Tracking \#: & $\mathrm{H}-21631$ & Page 5 of 5 & \\
Approved On: & $04 / 21 / 2009$ & & & \\
Valid Through: & $04 / 20 / 2010$ & & \\
Last Amended: & N/A & &
\end{tabular}


Appendix B

Parents As A Teacher Inventory 


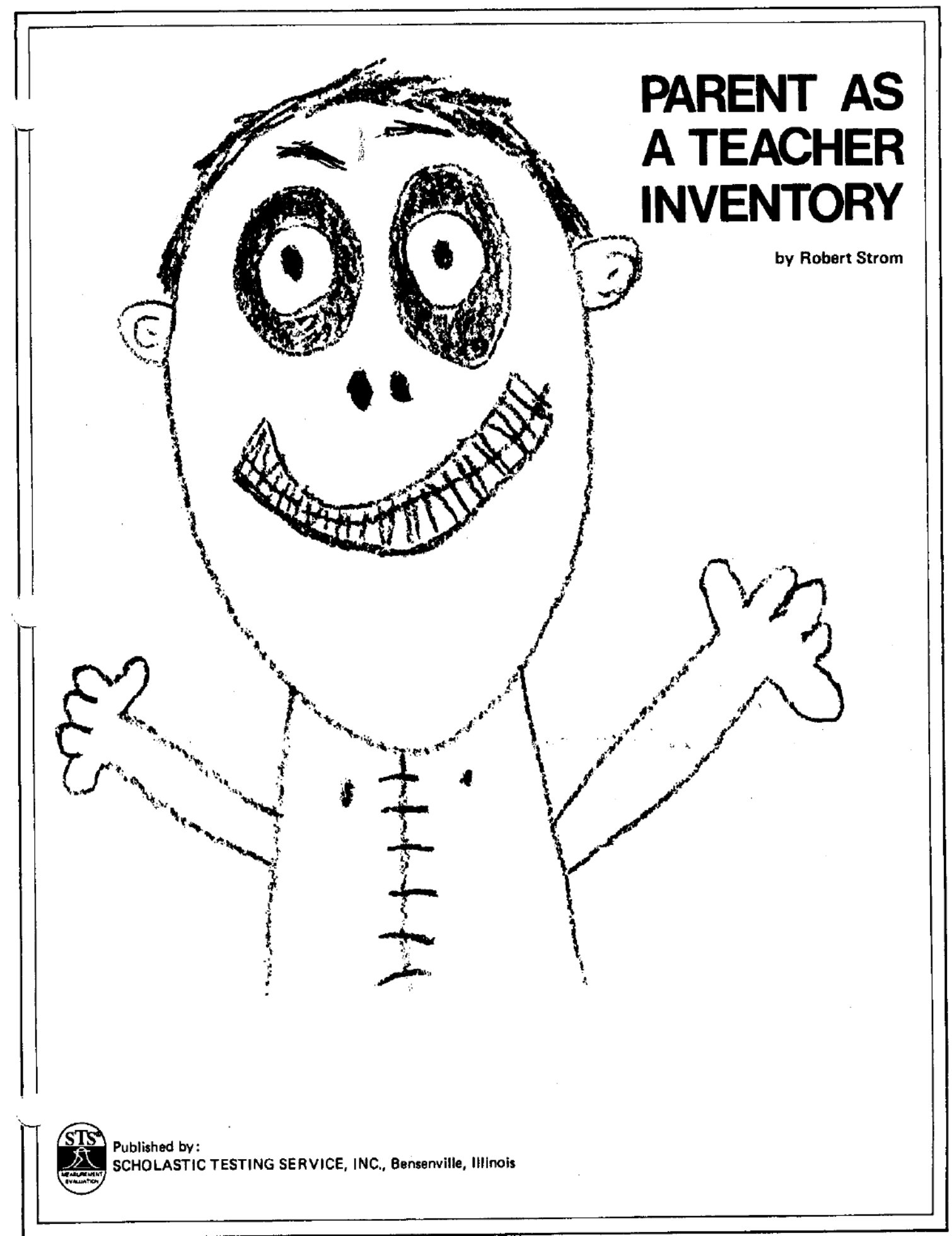


Directions:

You will be reading some statements on feelings about your child. This is not a test. We are asking that you express your feelings about your child. For each statement, circle only one answer. If there is no doubt in your mind about the statement, circle either STRONG YES or STRONG NO. Otherwise, circle either YES or NO. Continue until you have answered all 50 statements. Take your time.

1. I get tired of all the questions my child asks.

$$
\text { STRONG YES YES NO STRONG NO }
$$

2. My child should be able to make noise during play.

STRONG YES YES NO STRONG NO

3. It is all right for my child to disagree with me.

$$
\text { STRONG YES YES NO STRONG NO }
$$

4. My child needs to play with me.

$$
\text { STRONG YES YES NO STRONG NO }
$$

5. Much of my child's learning will take place before he or she enters school.

$$
\text { STRONG YES YES NO STRONG NO }
$$

6. I like my child to make up stories.

$$
\text { STRONG YES YES NO STRONG NO }
$$

7. It gets on my nerves when my child keeps asking me to watch him or her play.

$$
\text { STRONG YES YES NO STRONG NO }
$$

8 I want my child to say more than I do when we talk.

STRONG YES YES NO STRONG NO

9. Playing with my child makes me feel restless.

STRONG YES YES NO STRONG NO


10. It is hard for me to tell when my child has learned something.

$$
\text { STRONG YES YES NO STRONG NO }
$$

11. When my child doesn't know an answer, I ask the child to guess.

$$
\text { STRONG YES YES NO STRONG NO }
$$

12. I get tired of all the fears that my child talks about.

$$
\text { STRONG YES YES NO STRONG NO }
$$

13. There are some things I just don't want my child to talk about.

$$
\text { STRONG YES YES NO STRONG NO }
$$

14. If I spend a lot of time playing with my child, he or she will disobey me more often.

STRONG YES YES NO STRONG NO

15. It is all right for my child to have a make-believe friend.

$$
\text { STRONG YES YES NO STRONG NO }
$$

16. I want my child to play with toys made for boys and toys made for girls.

STRONG YES YES NO STRONG NO

17. My child bothers me with questions when I am busy.

$$
\text { STRONG YES YES NO STRONG NO }
$$

18. I like my child to be quiet when adults are talking.

$$
\text { STRONG YES YES NO STRONG NO }
$$

19. I feel able to choose new toys for my child.

$$
\text { STRONG YES YES NO STRONG NO }
$$

20. It is difficult for me to think of things to say to my child during play.

STRONG YES YES NO STRONG NO


21. When my child plays with toys, the pretending seems foolish.

$$
\text { STRONG YES YES NO STRONG NO }
$$

22. My child is punished for fighting during play.

$$
\text { STRONG YES YES NO STRONG NO }
$$

23. While we play, my child should be the person in control.

$$
\text { STRONG YES YES NO STRONG NO }
$$

24. Playing with my child improves the child's behavior.

$$
\text { STRONG YES YES NO STRONG NO }
$$

25. When I play with my child I feel the need to talk like a child.

$$
\text { STRONG YES YES NO STRONG NO }
$$

26. I want my child to have all of his or her questions answered.

$$
\text { STRONG YES YES NO STRONG NO }
$$

27. It's all right for my child to get dirty while at play.

$$
\text { STRONG YES YES NO STRONG NO }
$$

28. When at play with my child, I prefer games that have rules rather than the make-believe kind of play.

$$
\text { STRONG YES YES NO STRONG NO }
$$

29. My child learns new words when we play.

STRONG YES 'YES NO STRONG NO

30. I feel able to give my child the proper preschool experience at home.

$$
\text { STRONG YES YES NO STRONG NO }
$$

31. I get upset when my child tries to solve a simple problem in the wrong way.

$$
\text { STRONG YES YES NO STRONG NO }
$$


32. It's okay for my child to interrupt me when we play.

STRONG YES YES NO STRONG NO

33. I feel play must be stopped when my child becomes angry at a playmate.

$$
\text { STRONG YES YES NO STRONG NO }
$$

34. I try to praise my child a lot when we play.

$$
\text { STRONG YES YES NO STRONG NO }
$$

35. More of my child's personality learning at this age takes place by watching people and things rather than by being told.

$$
\text { STRONG YES YES NO STRONG NO }
$$

36. It is all right for my child to spend a lot of time playing alone.

$$
\text { STRONG YES YES NO STRONG NO }
$$

37. While at play my child can take out as many toys as he or she wishes.

$$
\text { STRONG YES YES NO STRONG NO }
$$

38. I provide chances for my child to make up his or her own mind about a lot of things.

STRONG YES YES NO STRONG NO

39. It is difficult for me to stay interested when playing with my child.

STRONG YES YES NO STRONG NO

40. I scold my child when he or she doesn't learn.

STRONG YES YES NO STRONG NO

41. My child wants to play too long at one time.

STRONG YES YES NO STRONG NO

42. When my child shows off I ignore it.

STRONG YES YES NO STRONG NO


43. I feel unhappy when I don't know an answer to my child's questions.

STRONG YES YES NO STRONG NO

44. I imitate my child's speech when we play so that the child understands.

$$
\text { STRONG YES YES NO STRONG NO }
$$

45. It is easy for me to use toys when teaching my child.

$$
\text { STRONG YES YES NO STRONG NO }
$$

46. I seldom tell my child his or her work is good or bad so that my child can be the judge.

STRONG YES YES NO STRONG NO

47. I want my child to put the toys away before going to bed.

STRONG YES YES NO STRONG NO

48. It's all right for my child to have secrets from me.

STRONG YES YES NO STRONG NO

49. My child learns by playing with other children.

STRONG YES YES NO STRONG NO

50. If we play whenever my child wants to, not much learning will take place.

STRONG YES YES NO STRONG NO


Appendix C - Academics 
51. It is not until children seem interested and persistent in writing their name and formatting letters when adults should offer assistance both informally and formally.

Strong yes yes no strong no

52. Before children leave the three year old class the children will be able to recite the alphabet; recognize many letter sounds, name shapes and colors. $\begin{array}{llll}\text { Strong yes } & \text { yes } & \text { no } & \text { strong no }\end{array}$

53. Children should not be hurried nor should they be made to wait for extended periods of time.

$\begin{array}{llll}\text { Strong yes } & \text { yes } & \text { no } & \text { strong no }\end{array}$

54. In the "Happy School", the teacher brings all four- year-olds together for 30 minutes so she can work with them on a different language. The children mostly watch teacher.

$\begin{array}{llll}\text { Strong yes } & \text { yes } & \text { no } & \text { strong no }\end{array}$




\section{Appendix D}

Parent Form 


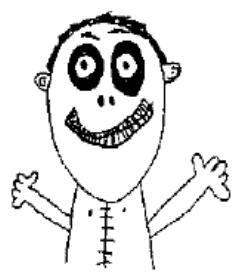

\section{PARENT AS A TEACHER \\ IDENTIFICATION OUESTIONNAIRE}

Child's Name

Your Name

(14) ID Number

Date

(5-6) Language of the PAAT

PLEASE ANSWER THE FOLLOWING QUESTIONS BY CHECKING THE CORRECT RESPONSE.

(7) My Child's Sex
(1) Male
(2)__ Female

$(8,9,10) \quad$ My Child's Age
(1)
Years
(2) Months

(11)

My Child's Present Grade Level:
(1) __ Preschool
(2) Kindergarten
(3) ___ First grade
(4)___ Second grade
(5) _ Third grade
(6) __ Fourth grade and above
(7) _ Other

(12) My Child's Ethnic Group:
(1) ____ Anglo/White
(2) __ Asian/Oriental
(3) ___ Black
(4) _uban
(5) ____ Mexican-American
(6) __ Native American Indian (7) __ Puerto Rican
(8) Other

(13) How many children are living in your home?

(14) What is the birth order of your child?
(1) _ First born
(2)__ Second born
(3) Third born
(4) __ Fourth born
(5)__ Fifth born
(6) ___ Sixth born
(7) __ Seventh born
(8) __ Eighth born
(9) _ Ninth born or greater

(15) What is your sex?
(1) _ Male
(2) ___ Female

(16) What is your relationship to this child?
(1) _ Father
(2) __ Mother
(3) ___ Grandfather
(4) Grandmother
(5) __ Guardian
(6) — Other

Copyright (c) 1984, Robert D. Strom. All rights reserved. No part of this work may be reproduced or transmitted in Copyright @ 1984 , Robert D. Strom. All rights reserved. No part of this work mating, or any information storage any form or by any means, electronic or mechanical, including publisher. Printed in the United States of America. Published by Scholastic Testing Service, Inc., Bensenville, IL 60106 
(17) What is your marital status?
(1) _ Married
(2) _ Separated
(3) Divorced
(4) Widowed
(5) _ _ Never married

(18) Your highest grade completed in school:
(1) ___ Graduate school degree
(2) __ Some graduate school
(3) College degree
(4) __ Some college
(5) _ Post high school training
(6) __ High school diploma
(7) __ Some high school
(8) _ Junior high school
(9) L__ Less than seven years of school

(19) What is your occupation?

(20) What is your current yearly household income?
(1) _ _ Under 4,999
(2) — 5,000 to 9,999
(3) ــ 10,000 to 19,999
(4) 20,000 to 29,999
(5) ـ 30,000 to 39,999
(6) ـ 40,000 to 49,999
(7) _ Over 50,000

(21-22) What language do you most often speak at home?
(1) Arabic
(2) __ English
(3) __ French
(4) __ German
(5)__ Greek
(6) Italian
(7) __ Japanese
(8) ___ Mandarin
(9) _ Spanish
(10)_ Turkish
(11)_ Vietnamese
(12) _ Other

(23) If your child is exceptional, indicate the category which best describes your child.
(1) ___ Mentally retarded
(2) _ Physically handicapped
(3) _ Multiply handicapped
(4) __ Sensory handicapped (Vision and/or hearing)
(5) ___ Emotionally handicapped
(6) ___ Speech handicapped
(7) ___ Learning disabled
(8) __ Gifted or talented
(9) Other

IF YOU ARE CURRENTLY MARRIED PLEASE ANSWER THE FOLLOWING QUESTIONS ABOUT YOUR SPOUSE:

(24) Spouse's highest grade completed in school:
(1)___ Graduate school degree
(2) __ Some graduate school
(3) … College degree
(4) ___ Some college
(5) __ Post high school training
(6) __ High school diploma
(7) ___ Some high school
(8) __ Junior high school
(9) ___ Less than seven years of school

(25) Spouse's occupation: 
Appendix E

Behavioral Academic Self-esteem 

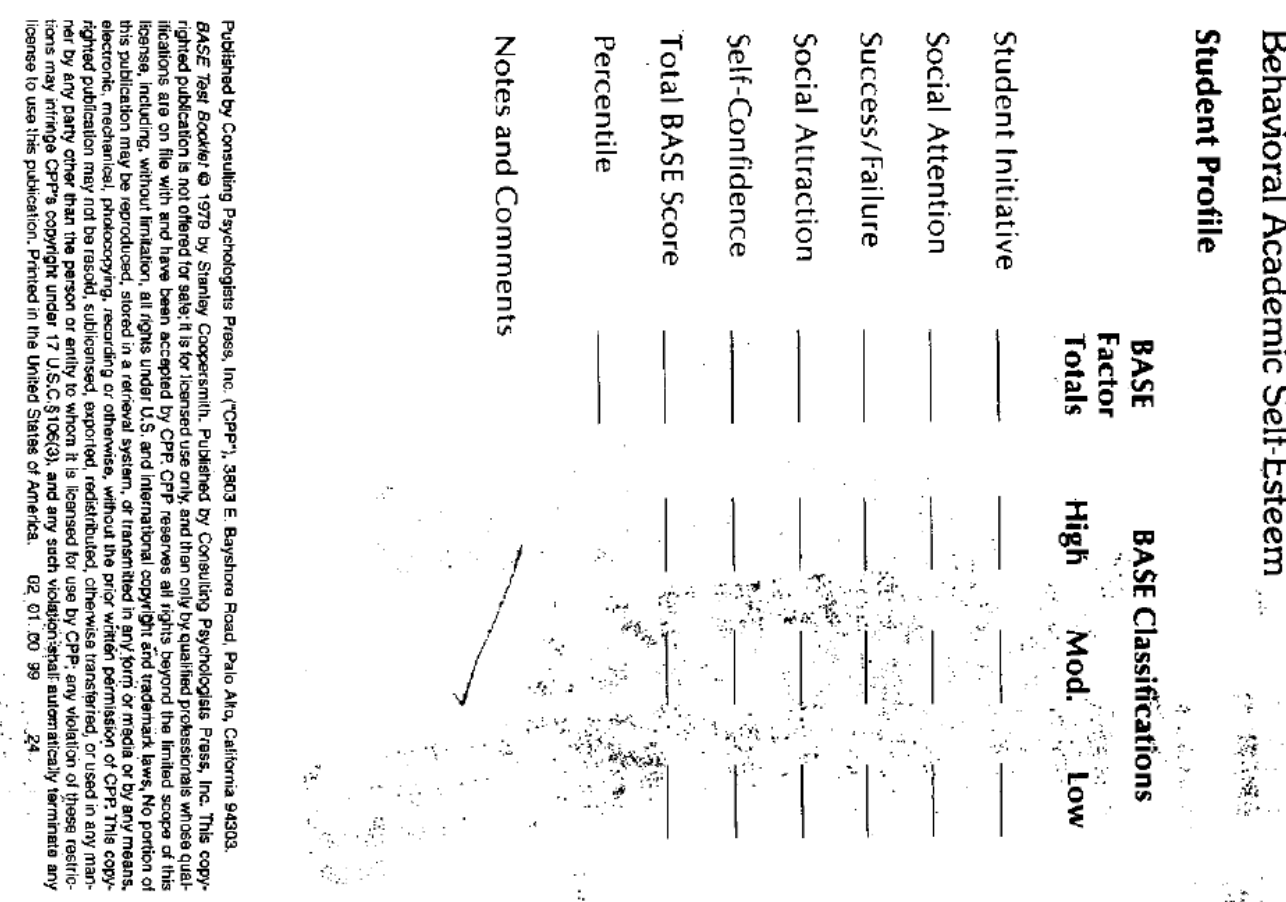

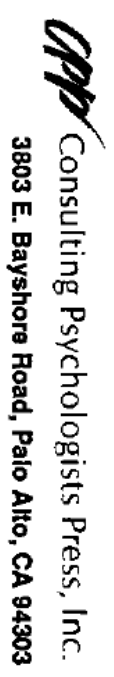
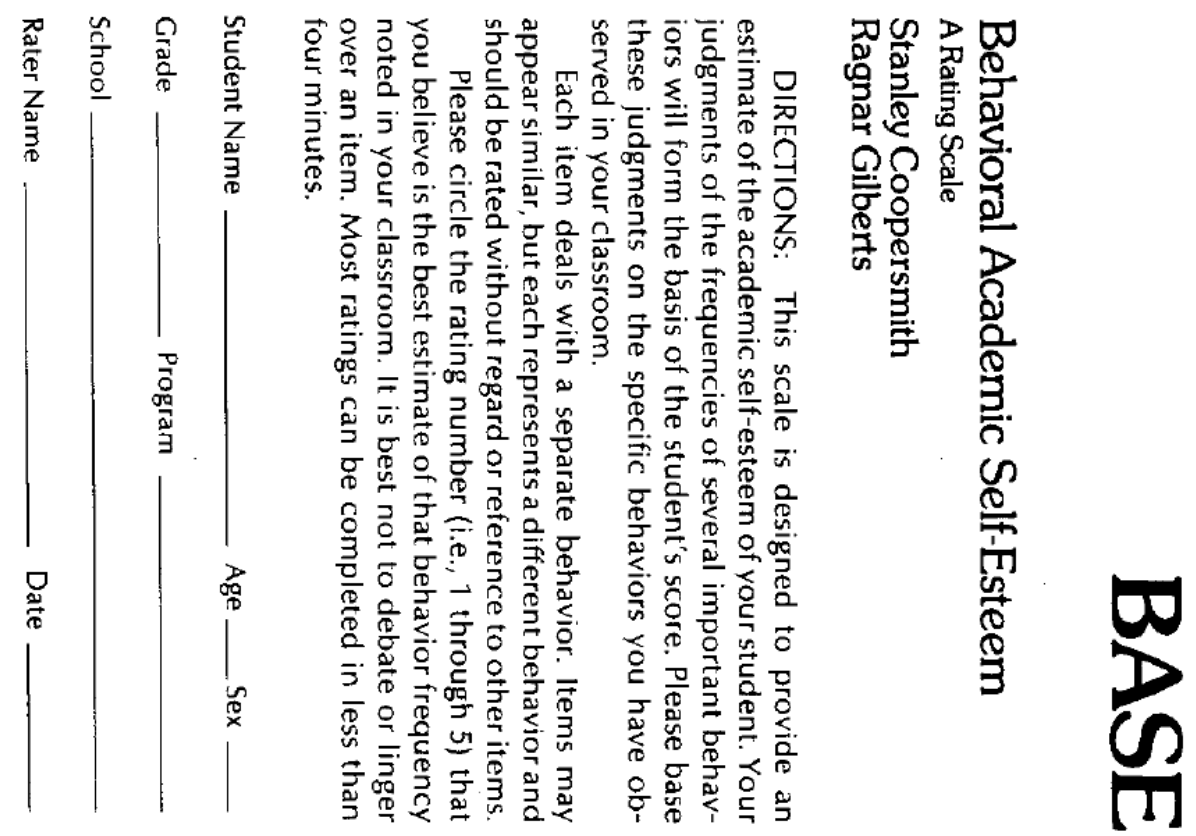

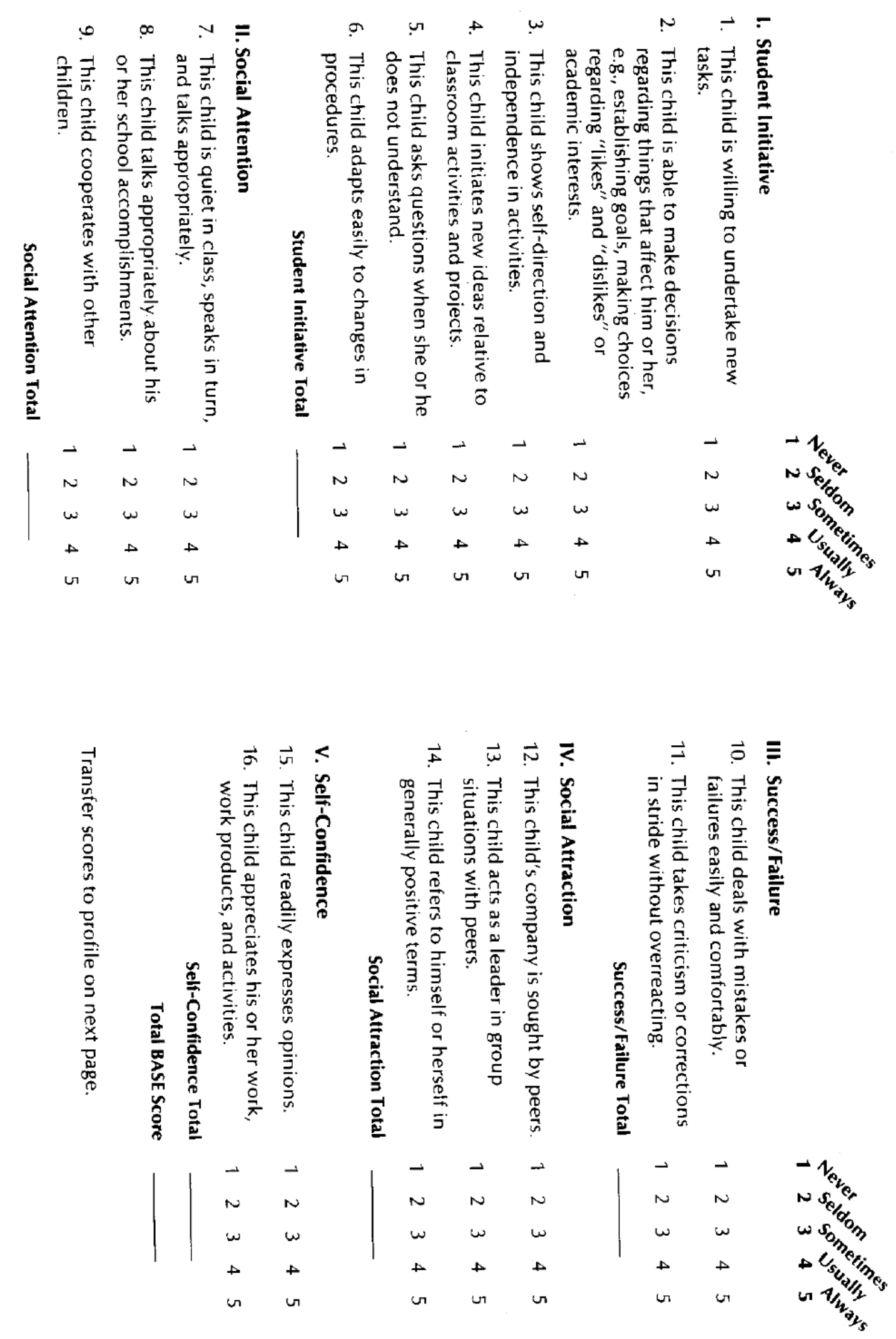


\section{Jill Martino}

College of Human Resources and Education

Masters of Art in Educational Psychology

Major: Child Development and Family Studies

May 2009

West Virginia University Morgantown, WV

G.P.A. -3.70

College of Human Resources and Education

Bachelor of Science in Family and Consumer Science

Major: Child Development and Family Studies

2003- 2007

University of Charleston Charleston, WV

2002- 2003

Credentials: State of West Virginia 21-1 Professional Teaching Certificate 3606 Birth- Pre-K Education Presented 12/29/2008

Expires 6/30/2012

Early Childhood Director's Credential - presented February 2007

Experience:

Director- KidzRock Summer Enrichment Program

Morgantown, WV Suncrest United Methodist Church May 2009 - present

Initiated the program- enrollment, orientation etc.

Planned and implemented daily activities - assessed needs/ interest of each child

Purchased supplies

Supervised and worked with all program staff

Provided positive parent contact/communication as well as communication with staff

Maintained written records/ reports

Prepared weekly schedule of staff/ substitutes and secured volunteers

\section{Graduate Assistant- Child Development and Family Studies \\ West Virginia University \\ Morgantown, WV \\ Assisted the professors with five classes \\ Created quizzes and Exams \\ Graded projects, tests, quizzes, and papers and entered them in the grading system \\ Created lectures and substituted for professors when needed \\ Advised undergraduates on course for scheduling}

August 2007 -May 2009

\section{Lead Teacher}

Morgantown, WV

West Virginia University - Nursery School

Summer 2008

Supervised student teachers during summer camp

Planned lessons on literacy/ writing development

Arranged activities for 3, 4, and 5 year olds' physical education through the WVU Student

Recreational Center

Teaching Assistant

Morgantown, WV $\quad$ Pleasant Day Schools $\quad$ Spring 2006 - August 2007

Assist lead teacher in lesson preparation and classroom organization

Provided care for eight two year olds during the afternoon session

\section{Practicum}

Morgantown, WV West Virginia University - Nursery School $\quad$ Spring 2006 \& 2007

Planned lessons for children age 3,4 , and 5 in both the morning and afternoon sessions 
Promoted West Virginia state curriculum for preschools

Worked to implement Reggio Emilia technique in the school

\begin{abstract}
Internship
Worked with both infants and toddlers

Observation of child's social, cognitive and behavioral learning

Analyzed motor development and assessed needs based on the individual

Worked with the child's strengths to gain confidence and aid in building underdeveloped skills

Planned activities to target specifics areas that needed greater attention

\section{Office Assistant - Preschool P.E. Laboratory (Practicum) \\ Designed games for children ages 5-12 and led station activities \\ Created activities to educate children about proper eating and exercise \\ Assumed lead instructor position if need be. \\ Assisted in recording attendance, charting student information, and organizing files.}

Morgantown, WV Choosy Kid's Club -WVU Motor Development Center Sept. - Dec. 2004

Awards: $\quad$ Greater Kanawha Valley Foundation Scholarship, Dean's List - Spring 2006, President's List (4.0) at West Virginia University- Fall 2005, Honoree at the Davis College Honors

Convocation -Spring 2006; Phi Delta Kappa International nominee - Fall 2006, Outstanding

Student for Child Development and Family Studies in the College of Human Resources and

Education- May 2007
\end{abstract}

Morgantown, WV Pleasant Day Schools

Fall 2005 \& 2006

Activities: Graduate Assistant in Child Development and Family Studies, Member of Phi Upsilon Omicron- National Honor Society in Family and Consumer Sciences -Historian (2006-2007), Treasurer (2008- 2009), Member of the Council for Exceptional Children ( CEC)- 2008-2009, Mountaineer Maniacs - leadership team (2007-2008), West Virginia Association for Young Children (student chapter), Italian American Organization of West Virginia University.

Professional Memberships: National Association for the Education of Young Children (NAYEC)

Southern Early Childhood Association (SECA)

West Virginia Association for Young Children (WVAYC)

Phi Upsilon Omicron - National Honor Society in Family and Consumer Sciences

Skills: $\quad$ Computer skills using Microsoft word, PowerPoint, Access and Excel as well as internet skills. Certified in First Aid and CPR

References available upon request

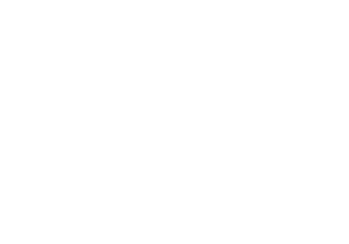

